\title{
Barents Sea polar bears (Ursus maritimus): population biology and anthropogenic threats
}

\author{
Magnus Andersen \& Jon Aars \\ Norwegian Polar Institute, Fram Centre, PO Box 6606 Langnes, NO-9296 Tromsø, Norway
}

\section{Keywords}

Top predator; environmental threats; climate warming; contamination;

disturbance; habitat change.

\section{Correspondence}

Magnus Andersen, Norwegian Polar Institute, Fram Centre, PO Box 6606 Langnes, NO-9296 Tromsø, Norway. E-mail: magnus.andersen@npolar.no

\begin{abstract}
This paper examines how anthropogenic threats, such as disturbance, pollution and climate change, are linked to polar bear (Ursus maritimus) population biology in the Svalbard and Barents Sea area, with the aim to increase our understanding of how human activity may impact the population. Overharvesting drastically reduced the population of polar bears in the Barents Sea region from about 1870 to 1970. After harvesting was stopped-in 1956 in Russia and 1973 in Norway-the population grew to an estimated 2650 individuals (95\% confidence interval 1900-3600) in 2004, and maternity denning in the Svalbard Archipelago became more widely distributed. During recent decades, the population has faced challenges from a variety of new anthropogenic impacts: a range of pollutants, an increasing level of human presence and activity as well as changes in ice conditions. Contaminants bioaccumulate up through the marine food web, culminating in this top predator that consumes ringed, bearded and harp seals. Females with small cubs use land-fast sea ice for hunting and are therefore vulnerable to disturbance by snowmobile drivers. Sea-ice diminution, associated with climate change, reduces polar bears' access to denning areas and could negatively affect the survival of cubs. There are clear linkages between population biology and current anthropogenic threats, and we suggest that future research and management should focus on and take into consideration the combined effects of several stressors on polar bears.
\end{abstract}

The history of polar bear (Ursus maritimus) science has involved extensive international cooperation in research and management over the last 50 years (Larsen \& Stirling 2009). Polar bears are widely distributed across the circumpolar Arctic, including regions of drifting sea ice. The world population size is suggested to be 20000-25000 animals, comprising 19 subpopulations (Obbard et al. 2010). Polar bears are specialized predators that mainly feed on seals and other marine mammals (Stirling $\&$ Archibald 1977; Smith 1980; Derocher et al. 2002; Iversen et al. 2013). Characterized as marine mammals themselves, polar bears rely on sea ice not only to gain access to their prey but also to travel between hunting and denning habitats. Though they den on land throughout most of their range, sea ice is also important for reproduction in most polar bear populations because males search the sea ice in spring to locate mates (Molnár et al. 2008).
Polar bears are highly mobile and individuals can roam over large areas. However, significant variations in movement behaviours have been documented even within populations, with home ranges varying from less than $200 \mathrm{~km}^{2}$ to almost $400000 \mathrm{~km}^{2}$ in the Barents Sea region (Mauritzen et al. 2001). In Svalbard, some bears move over the entire Barents Sea during their annual seasonal movements while others remain within the Svalbard Archipelago (Wiig 1995; Mauritzen et al. 2001). Polar bears are generally found in low densities throughout the Arctic, but can also concentrate close to or on land during parts of the year. This can occur during maternity denning in winter, for example, in Kong Karls Land, Norway (Larsen 1986), or during summer and autumn, when they are stranded until the sea ice freezes, for example, in Hudson Bay, Canada (Derocher \& Stirling 1990). 


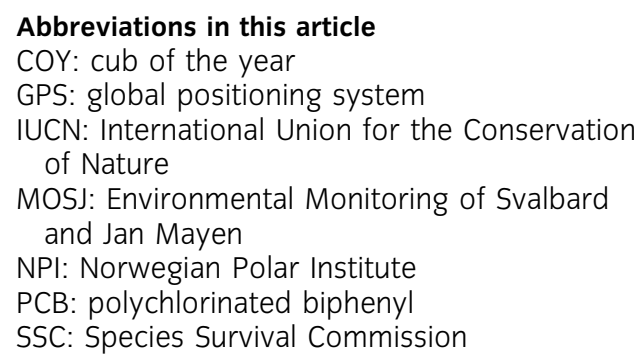

The first to describe the population biology of polar bears in Norway, Lønø (1970) analysed all available data on polar bear hunting in Svalbard up to a few years before protection of the population was enacted. His work documented the very high take of polar bears in this region from about 1870 to 1970 . Between 100 and 900 bears were shot annually in northern Greenland and the Barents Sea region during this period. It soon became apparent that the population was in danger of being extirpated if the harvest was allowed to continue with only limited controls (Anonymous 1966). The same situation was seen in other Arctic regions, spurring international action to protect polar bears (Prestrud \& Stirling 1994).

Initiatives among the polar bear nations-Canada, Denmark (now Greenland), Norway, the Soviet Union (now Russia) and the USA-which were facilitated by the IUCN, resulted in the signing of the Agreement on the Conservation of Polar Bears (hereafter called the Agreement) in 1973 (www.pbsg.npolar.no/en/agree ments/agreement 1973.html). Article II of the Agreement states that:

... each Contracting Party shall take appropriate action to protect the ecosystems of which polar bears are a part, with special attention to habitat components such as denning and feeding sites and migration patterns, and shall manage polar bear populations in accordance with sound conservation practices based on the best available scientific data.

Article VII states that to achieve this goal:

... the Contracting Parties shall conduct national research programmes on polar bears, particularly research relating to the conservation and management of the species. They shall as appropriate coordinate such research with research carried out by other Parties, consult with other Parties on the management of migrating polar bear populations, and exchange information on research and management programmes, research results and data on bears taken.
During the period between the first meeting among polar bear nations in 1965 and the signing of the Agreement, the negotiating parties established the IUCN/SSC Polar Bear Specialist Group, which provided the scientific basis for the Agreement. The Polar Bear Specialist Group has managed the Agreement and guided national authorities in their management of polar bears, and since 2009 it has served as an independent advisor to the Parties of the Agreement. Polar bears have now been included in the Bern Convention on the Conservation of European Wildlife and Natural Habitats and the Convention on International Trade in Endangered Species of Wild Fauna and Flora. In Norway, the Svalbard Environmental Protection Act includes several regulations to protect polar bears and their habitat. The Norwegian Ministry of Climate and Environment, which is responsible for nature conservation and management in Norway, has ambitious goals for the management of Svalbard and its wildlife. Status of polar bears and population threats are therefore specifically dealt with in the Management Plan for Lofoten and the Barents Sea (Anonymous 2010), which was presented to the Norwegian Parliament in March 2006 and revised in 2010.

The first report of the Intergovernmental Panel on Climate Change to mention the consequences of climate change for sea-ice cover in the Arctic was the third assessment (Houghton et al. 2001). Based on this report, the IUCN asked the Polar Bear Specialist Group for a new evaluation of the international Red List status of polar bears, leading to a classification change from Near Threatened to Vulnerable in 2006. As part of the work with the national evaluation in the USA, under the Endangered Species Act, the US Fish and Wildlife Service called for a meeting in 2007. Polar bear authorities from all polar bear nations, known as Range States, were invited to exchange information about polar bear research and management and to discuss the status of populations and measures to conserve the species. It was agreed that a meeting of the parties to the Polar Bear Agreement of 1973 should be held biannually. During the meetings in 2009 and 2011, the main goal was to develop a range-wide action plan for polar bears, and this work was finalized in September 2015 (Polar Bear Range States 2015).

These initiatives came as a response to concerns that had been raised about climate change effects on polar bears. Global warming (Comiso 2002; Core Writing Team et al. 2007; Comiso et al. 2008) is believed to represent a threat to polar bear populations throughout their range on account of the declining area, connectivity (Sahanatien $\delta$ Derocher 2012) and suitability of sea-ice habitats for bears (Stirling \& Derocher 1993; Derocher et al. 2004; Amstrup et al. 2008; Wiig et al. 2008; Durner et al. 2009; 
Molnár et al. 2010; Molnár et al. 2011). The decrease in habitat for polar bears and their main prey, ringed seals (Pusa hispida), may lead to a reduction in population sizes and possibly to complete loss of some populations (Amstrup et al. 2008; Durner et al. 2009; Amstrup et al. 2010; Molnár et al. 2010). The Barents Sea population has been identified as one of the populations where predicted reductions in sea ice in coming decades are particularly severe (Durner et al. 2009).

In 2010, under the auspices of the Arctic Council working group Conservation of Arctic Flora and Fauna, an initiative was taken to develop a circumpolar monitoring plan for polar bears. A background paper was presented at the working group's biennial meeting in February 2011 (Vongraven \& Peacock 2011), and a circumpolar monitoring framework has been developed (Vongraven et al. 2012). This framework identifies several threats and stressors to polar bear populations, identifies recommended monitoring parameters and knowledge gaps and suggests how to fill these gaps and improve monitoring. The conclusions are in agreement with threats previously identified for the Barents Sea population in a plan designed to monitor Svalbard and Jan Mayen (Sander et al. 2005), but argue that a more comprehensive monitoring programme is needed on a circumpolar level to coordinate monitoring activities, utilize monitoring capacities in a more efficient manner and facilitate monitoring that feeds into an adaptive management regime. The framework presented by Vongraven et al. (2012) uses the ecoregion classification concept, outlined in Amstrup et al. (2008). Polar bear populations throughout the Arctic are categorized according to the characteristics and predicted changes in the sea-ice habitat (divergent, convergent, archipelago and seasonal sea ice). Vongraven et al. (2012) recommend that high-intensity monitoring should be conducted in at least six of the 19 polar bear populations throughout the Arctic; the Barents Sea is one of the suggested areas. The Barents Sea population is chosen as a representative of a divergent sea-ice ecoregion (Amstrup et al. 2008) because baseline data are available, there is a high risk of climate change effects and high contaminant levels are likewise documented.

The first polar bear was live-captured and tagged as part of the Norwegian polar bear research programme in 1966 (Larsen 1967, 1970), initiating a new era in polar bear research and management in the region. In the years following, a range of population studies was conducted (e.g., Harington 1965; Lentfer 1969; Jonkel 1970; Larsen 1972). In 1975, concern was raised for the first time regarding high levels of pollutants found in polar bear tissues (Bowes \& Jonkel 1975). Contaminants continue to be a significant threat to polar bear health
(Letcher et al. 2010; Obbard et al. 2010; Sonne 2010; Dietz, Basu et al. 2013; Dietz, Rigét et al. 2013) and recent findings regarding effects on immune responses and metabolism highlight the complexity of this issue (Braathen et al. 2004; Lie et al. 2004, 2005; Villanger et al. 2011). Today, polar bears are included in several monitoring programmes because they are seen as indicators of the environmental condition of the Arctic and because of international obligations: MOSJ (Sander et al. 2005), Arctic Monitoring and Assessment Program (Nilsson \& Huntington 2009) and Conservation of Arctic Flora and Fauna (Vongraven $\&$ Peacock 2011 ; Vongraven et al. 2012).

Since the legal protection of polar bears in Svalbard was enacted in 1973, the NPI has been responsible for Norway's polar bear research and monitoring programme. The main aim of the programme has been to supply knowledge needed by management authorities. While maintaining its long-term perspective, the programme has adapted to answer new questions as they have arisen. The main focus of the NPI programme was initially to study the effect the century-long period of hunting had had on the population, but later pollution, anthropogenic activity and tourism and, most recently, climate change have been prioritized issues.

In the following review, we describe key aspects of polar bear population biology in Svalbard and the broader Barents Sea region after hunting stopped in 1973. Further, we explore potential impacts of new threats such as seaice change, human disturbance and pollution on polar bears, while also considering ecosystem effects. Findings in the literature are discussed in relation to future management and monitoring of polar bears in the region.

\section{Population biology and linkages to threats}

\section{Population history}

The Barents Sea polar bear population is shared between Norway and Russia (Mauritzen et al. 2002) and has been protected against hunting since 1956 in Russia and 1973 in Norway (Prestrud \& Stirling 1994). Capture-recapture and satellite telemetry data reveal that the population is distributed from Svalbard in the west and Franz Josef Land in the east. In between these land masses, polar bears are found in the ice-covered parts of the Barents Sea and the Arctic Ocean (Wiig 1995; Mauritzen et al. 2002; Fig. 1). Larsen (1986) suggested that there were between 3000 and 6700 polar bears (depending on the population borders) in the Barents Sea at the beginning of the 1980s. This was based on data from multiple sources, including den counts and spatially restricted non-random 


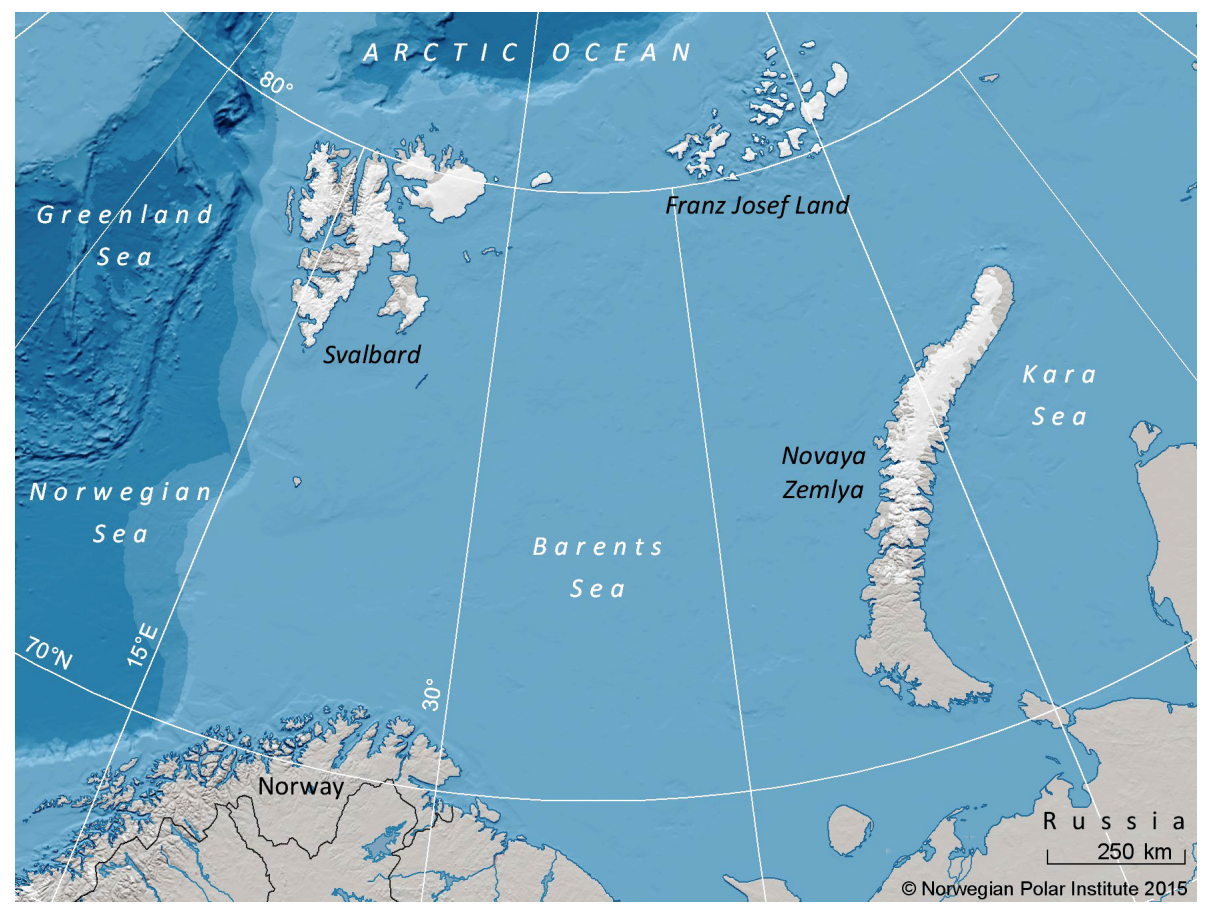

Fig. 1 The Barents Sea and surrounding land areas. The Barents Sea polar bear population is distributed from Svalbard in the west to Franz Josef Land in the east. The majority of the polar bears in the population is found in sea-ice covered areas between, and north of, these archipelagos.

aerial surveys, which were extrapolated to larger areas. No study covering the whole area in question had been undertaken prior to the survey conducted in 2004 (Aars et al. 2009). Most population estimates for polar bears have been derived using capture-recapture methods (e.g., DeMaster et al. 1980; Taylor et al. 2005). Obtaining sufficiently large sample sizes is time consuming and expensive (Wiig \& Derocher 1999), but the method yields valuable data on individuals for a range of other population ecology studies. Recent statistical developments have made distance sampling one of the most widely used methods for estimating animal abundance in the last decade (Buckland et al. 2004) and it is today regarded as being more cost efficient than capture-recapture to achieve high levels of precision (Borchers et al. 2002), in particular for populations occurring at low densities over large areas.

Aars et al. (2009) concluded that the Barents Sea population had approximately 2650 (95\% confidence interval approximately 1900-3600) bears in August 2004. They found significant geographic variability in densities of bears across different types of habitats in the study area. The density of bears on land-fast ice and pack ice in the Russian areas to the east was much higher ( $>2$ bears/ $\left.100 \mathrm{~km}^{2}\right)$ than in the Norwegian territory $(0.4-1$ bears/ $100 \mathrm{~km}^{2}$ ). The mean density of polar bears across the whole region was, however, close to the densities described elsewhere in the Arctic (Taylor \& Lee 1995; Evans et al. 2003). Polar bear spatial patterns are known to vary with both season and year. Individual polar bears in the Barents Sea show high seasonal fidelity to specific areas (Mauritzen et al. 2001). Many of the polar bears that are distributed around the islands of Svalbard in spring are distributed along the ice edge further northeast in the Russian area and around Franz Josef Land in August. During the survey in 2004 there were three times as many bears in the Russian parts of the northern Barents Sea compared to the Norwegian area (Aars et al. 2009). Both the number of maternity dens (Larsen 1986; Andersen et al. 2012) and the relatively high number of recaptures of bears in the Svalbard area (Derocher 2005) indicate that more polar bears are present in the Svalbard area in spring compared to other times of the year. This is partly explained by the need for pregnant females to find suitable denning habitat on land and raise cubs in a stable ice habitat in spring. Bears may also be attracted by the generally good breeding habitat for ringed and bearded seals (Erignathus barbatus) in Svalbard fjords and the resulting good spring hunting habitat for the polar bears, particularly on the east coast (Derocher et al. 2002; Andersen et al. 2012; Freitas et al. 2012).

How the significant changes in the sea-ice habitat recently taking place in the Barents Sea may affect the 
polar bear population in the long run is unknown. A possible scenario, based on what we know about space use strategies, is a stronger separation between pack-ice bears and those that use habitat closer to and on land. If this unfolds, population boundaries and definitions may have to be re-evaluated.

\section{Harvest history}

The initial threat to polar bears in the region was unquestionably overharvest. Bear numbers were reduced quite drastically between 1909 and 1970 when an average of 320 polar bears were harvested annually in Svalbard and adjacent areas (Lønø 1970). Assuming an even sex ratio in the harvest, the sustainable take of a closed polar bear population under optimal conditions is considered to be $3.2 \%$ (Taylor et al. 1987). This implies that the Barents Sea population should have numbered at least 10000 polar bears to have sustained the recorded harvest. The harvest obviously was not sustainable, but the calculation still indicates that the historical population size must have been significantly higher than the current size. The large difference between this number and the upper confidence limit (3600) of our estimate in 2004, after 40 years of protection, is noteworthy. Larsen (1986) indicated that the population approximately doubled in size over a decade after protection in 1973 and suggested that there were close to 2000 bears in the Svalbard area and 3000-6700 in the area between East Greenland and Franz Josef Land in 1980. The growth rate from then and up to 2004 is unknown. Changes in population age structure suggest that population growth has been positive, but also that the growth rate today is much lower than earlier (Derocher 2005). One possible explanation for the large difference in the estimated size in 2004 and the theoretical historical size $(10000)$ could that the latter was expanded by significant immigration from less hunted neighbouring areas. However, the discrepancy between the recent estimate and the historical harvest levels is so significant that it is not likely that migration alone can explain the difference. Aars et al. (2009) speculate that either the population size today is far from the carrying capacity of the region or the carrying capacity has changed. Derocher et al. (2003) and Derocher (2005) suggested that the population recovery may have been slow after protection because high levels of organic pollutants (e.g., Andersen et al. 2001) in polar bears in the region have had a negative effect on survival and reproductive rates (Derocher 2005). The time needed for the population to recover to its carrying capacity could therefore be longer than suggested by demographic rates typical for other, less polluted, populations. The carrying capacity in the area may also have decreased during the last few decades and may continue to decrease in the future as a response to sea-ice loss (Derocher 2005; Heggberget et al. 2006; Durner et al. 2009; Wiig et al. 2015).

\section{Space use and sea-ice change}

It is believed that polar bear habitat in Svalbard and the Barents Sea will be significantly reduced during the coming decades and it has been suggested that the population will decrease as a consequence (Amstrup et al. 2008; Durner et al. 2009; Amstrup et al. 2010). The main reason is the loss of the platform needed for hunting ice-associated prey (Stirling \& Archibald 1977; Smith 1980; Derocher et al. 2002; Thiemann et al. 2008). Sea ice is also a platform for mating and travelling to and from terrestrial maternity denning areas (Wiig et al. 2008; Derocher et al. 2011). Evidence of decline in polar bear body condition, reproductive success, survival and abundance has been documented in the Canadian Arctic and the Beaufort Sea in Alaska, and the decline is thought to be caused by nutritional limitations imposed by diminishing sea ice (Stirling et al. 1999; Regehr et al. 2007; Regehr et al. 2010; Rode et al. 2010; Stirling \& Derocher 2012). In Svalbard, lowered body condition in the year after a bad ice year has been seen in male polar bears (MOSJ: www.mosj.npolar.no/en/fauna/marine/in dicators/polar-bear.html). To make reliable predictions about the future impacts of climate change on polar bears, it is essential to describe habitat use and identify especially important habitats.

The use of satellite telemetry in the study of polar bear movement and distribution was first applied between Svalbard, Norway and Greenland in 1979, when polar bears were equipped with satellite transmitters (Larsen et al. 1983). One of the latest technological developments for studies of wildlife has been to use GPS to determine the location of animals (e.g., Johnson et al. 2002; Frair et al. 2004; Gau et al. 2004; Morales et al. 2004), and to use the Argos System to collect these data from the transmitters remotely (e.g., Yasuda \& Arai 2005; Parks et al. 2006; Andersen et al. 2008).

GPS collar technology gives the opportunity to explore polar bear habitat use on a fine scale (Freitas et al. 2012). Previous studies have shown that polar bear distribution is significantly affected by sea-ice concentration and sea-ice type. Polar bears typically select ice concentrations ranging from 25 to $100 \%$, depending on the season and the region (Stirling et al. 1993; Arthur et al. 1996; Ferguson, Taylor \& Messier 2000; Ferguson et al. 2001; Mauritzen et al. 2003; Durner et al. 2009). In the Canadian Arctic, 
females with COYs select land-fast ice with pressure ridges during the spring, while lone adult females and males show strong preferences for ice-edge areas (Stirling et al. 1993). Females with COYs were thought to select landfast ice habitats to feed on ringed seal pups and also to avoid adult males, which are rare in this habitat; male bears sometimes prey on cubs (Stirling et al. 1993). In Svalbard and the Barents Sea area, female polar bears with COYs also show a year-round tendency to be located on more solid ice than lone adult females (Mauritzen et al. 2003).

Freitas et al. 2012 found that female polar bears with COYs predominantly occupied inshore land-fast ice areas during spring (April), and within this habitat they spent most time close to glacier fronts. In an aerial, survey study in the Canadian Arctic, Stirling et al. (1993) also reported that females with COYs showed a strong preference for land-fast ice during spring. However, in Svalbard they concentrated their time in land-fast ice close to glacier fronts while in the Canadian Arctic they selected fast-ice with snow drifts along pressure ridges, which were sometimes located far offshore. These preferred areas, in the respective locations, are linked to ringed seal pupping habitat. Ringed seals give birth during spring inside lairs that are constructed in snow that accumulates in stable sea-ice areas (Smith \& Stirling 1975; Kingsley et al. 1985; Furgal et al. 1996). Nutritionally stressed polar bear females with COYs need a predictable food source when emerging from their maternity dens in spring so these ringed seal pupping areas are a vital resource. In such areas, the female bears hunt ringed seal pups and sometimes their mothers (Stirling \& McEwan 1975; Pilfold et al. 2012; C. Lydersen, pers. comm.) without having to move long distances. Accordingly, most females with COYs in the study by Freitas et al. (2012) spent their entire tracking period/ spring in the land-fast ice habitats, close to known denning areas (Andersen et al. 2012).

Ringed seals occur in high densities in land-fast ice areas (Krafft et al. 2007) during April and bearded seals and harp seals (Pagophilus groenlandicus) also occur in the pack ice close to shore around Svalbard during spring (Haug et al. 1994; Isaksen \& Wiig 1995). All of these species have been recorded in the diet of polar bears from this area (Lønø 1970; Derocher et al. 2002; Iversen et al. 2013). Even if seal density is lower in the pack ice, bearded and harp seals are larger prey and represent a larger energy package for polar bears than ringed seals. Female polar bears in Svalbard may face a trade-off between exploiting land-fast ice that provides a safe substrate for cubs as well as a predictable and relatively high-density supply of small prey items and exploiting less stable drift ice, where prey are larger but their availability is more unpredictable and they occur at lower densities.

The study by Freitas et al. (2012) clearly emphasizes the importance of coastal fast-ice, in particular close to glacier fronts, for polar bear females with young cubs in Svalbard. Reductions in the extent of land-fast ice have been observed in recent years in Svalbard (Haarpainter et al. 2001; Gerland \& Hall 2006; Gerland et al. 2007; Høyland 2009). Glacier fronts that calve into the ocean, churning up nutrients and attracting wildlife, have also retreated inland in Svalbard in recent years (Blaszczyk et al. 2009). The eventual disappearance of these preyrich and stable sea-ice habitats close to the preferred denning habitat where polar bear with COYs concentrate during spring is likely to alter present distribution and hunting patterns and ultimately also reduce the reproductive rate of females and survival of cubs.

\section{Den distribution in Svalbard}

The use of maternity dens in snow is a characteristic adaptation in polar bears to the harsh Arctic environment (Blix \& Lentfer 1979). Polar bears typically den at low densities throughout the circumpolar Arctic, but concentrated denning areas exist at Wrangel Island, Russia (Belikov 1980), Kong Karls Land, Svalbard (Larsen 1985), and south-west Hudson Bay, Canada (Jonkel et al. 1972). Most maternity dens are located on land, although a few are made in multi-year sea ice off the Alaskan coast (Harington 1968; Lentfer 1975; Amstrup \& Gardner 1994; Fischbach et al. 2007). In Hudson Bay, polar bears den in earth dens that can be up to $80 \mathrm{~km}$ from the coast, but bears move into snow dens as snow accumulates in autumn (Jonkel et al. 1972; Richardson et al. 2005). Denning philopatry among female polar bears has been shown in Hudson Bay (Ramsay \& Stirling 1990), in Svalbard (Zeyl et al. 2010) and the Beaufort Sea (Amstrup \& Gardner 1994).

Andersen et al. (2012) found that most maternity dens in Svalbard are close to the coast $(<10 \mathrm{~km})$. Denning occurs in most parts of Svalbard, but the number of dens seems to be highest in the eastern parts of the archipelago (Fig. 2). The six most important denning areas are: (1) north-western Spitsbergen, (2) southern Spitsbergen, (3) northern parts of Nordaustlandet, (4) Barentsøya and Edgeøya, (5) Kong Karls Land and (6) Hopen (Fig. 2). The scarce data available indicate that polar bears captured in Svalbard or in the central parts of the Barents Sea also den in the Franz Josef Land Archipelago, as noted by Wiig (1998).

Lønø (1970) suggested that denning in Svalbard was restricted to the eastern parts, including Kong Karls Land, 


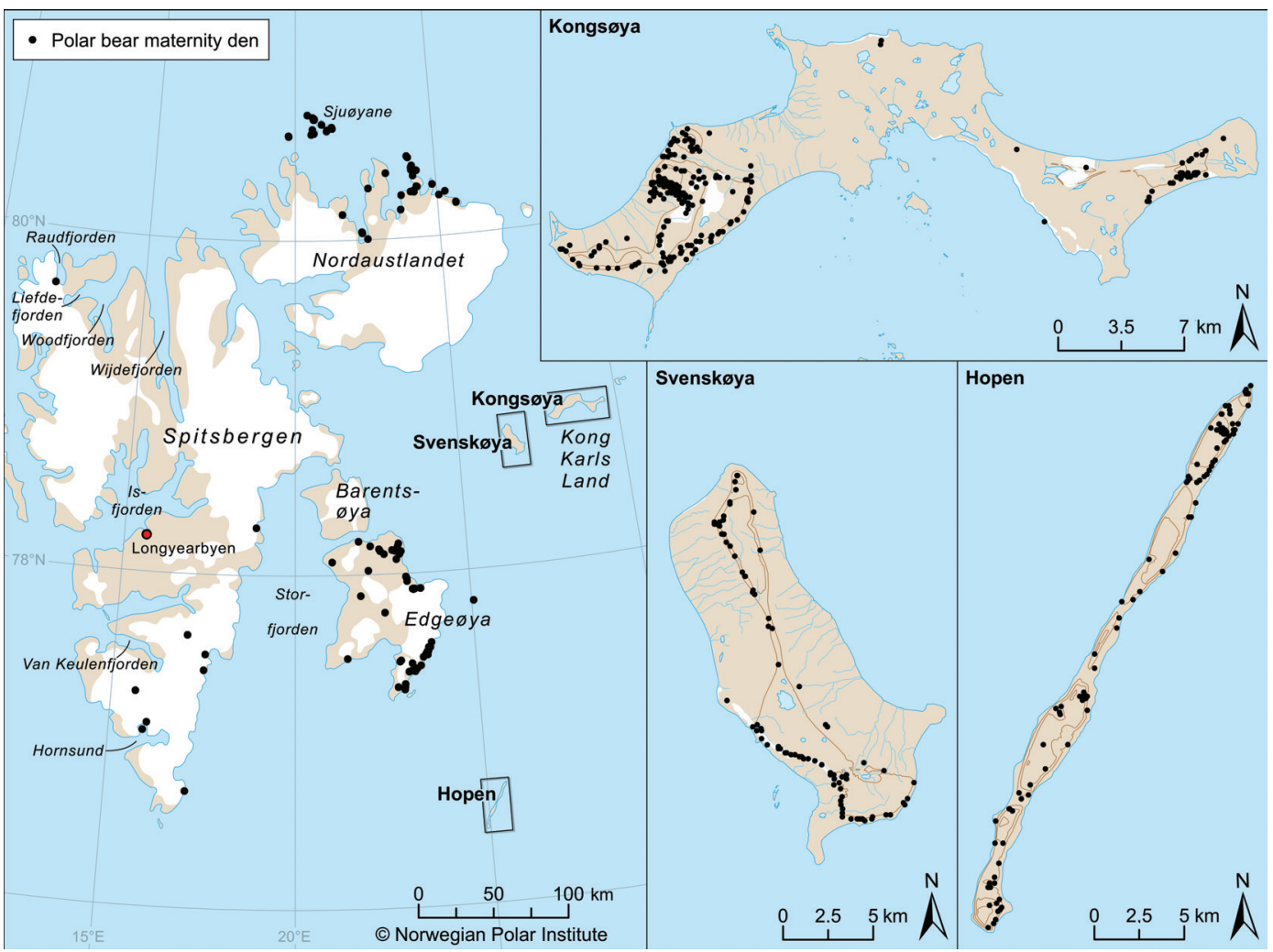

Fig. 2 Distribution of polar bear dens recorded in the Svalbard area $(n=534)$ during ground and aerial surveys, accumulated from 1972 to 2010. (From Andersen et al. 2012).

Nordaustlandet and along the northern part of the east coast of Spitsbergen. Larsen (1985) concluded that Kong Karls Land was the main denning area and that $90 \%$ of all dens in the archipelago were on the islands Edgeøya, Barentsøya, Nordaustlandet and Kong Karls Land. The small island Hopen was not considered an important denning site by Lønø (1970) or Larsen (1985), because only a few observations of dens or females with COYs had been made there. We believe that denning distribution in Svalbard is currently wider than it was in the decades before protection from hunting in 1973. We suggest that this apparent expansion is a result of re-establishment of denning areas after a long period of harvest. Fidelity to denning areas by female polar bears (Ramsay $\&$ Stirling 1990; Zeyl et al. 2010) might have delayed re-establishment associated with the population recovery.

Factors determining the distribution of polar bear dens are poorly understood, but in Svalbard some areas can only be used for denning if sea ice reaches them in autumn, making them accessible (Derocher et al. 2011). The linkage between denning and sea-ice conditions has also been described by others (Ferguson, Taylor, Rosing-Asvid et al. 2000). Early snow cover is also necessary in most areas, and the terrain is important for snow accumulation. In the
Beaufort Sea, about half of the dens were on drifting pack ice, half on land and some few on land-fast ice (Amstrup \& Gardner 1994). There has been no evidence of offshore denning in Svalbard (Lønø 1970; Larsen 1986), and the highly dynamic sea-ice conditions in the region may explain why this behaviour is not seen.

The findings of Andersen et al. (2012) indicate that most denning areas in Svalbard are close to fast-ice areas where ringed seals give birth to their pups. This agrees well with the finding of Freitas et al. (2012) that in April females with COYs use land-fast ice areas and single females or females with older cubs use other habitat types more frequently.

\section{Effect of historical harvest on denning}

Human activities can influence polar bear denning distribution (Lentfer \& Hensel 1980; Stirling \& Andriashek 1992; Amstrup 1993). Much of Svalbard's long history of polar bear harvesting involved the very effective but nonselective use of set-guns-baited guns, typically built into wooden boxes. Females emerging from dens with COYs were particularly vulnerable (Lønø 1970). Larsen (1985) argued that denning in the Edgeøya region had been heavily affected by more than 70 years of hunting, 
and that after 10 years of protection the area was again used frequently for denning. The same could be the case for Hornsund in the south and the fjords in the north of Spitsbergen, because both of these areas also experienced high hunting pressure during the decades before protection in 1973.

Trappers and station personnel hunted bears on Hopen from the early 1900s onwards (Lønø 1970). During the early to mid-1900s only two dens were recorded on Hopen (Lønø 1970). The reason for the larger number of dens on the island during the years 1995-2008 (Derocher et al. 2011) compared to the earlier period, when sea ice was likely more suitable for denning, is unknown, but it may be related to the difference in the number of adult females in the population. Between 1945 and 1970, an average of 41 bears per year was harvested at Hopen and from 1946 to 1968 altogether 951 bears were hunted there (Lønø 1970). The population was thought to have been depleted before hunting ended in 1973 (Larsen 1986; Prestrud \& Stirling 1994) and protection allowed the population to recover over the next 30 years (Derocher 2005). The larger number of maternity dens observed in later years may be a result of the reestablishment of Hopen as a denning area as the population increased (Aars et al. 2009; Derocher et al. 2011).

\section{Sea-ice change and denning}

Andersen et al. (2012) and Freitas et al. (2012) describe den distribution and female habitat use just after den emergence in spring, respectively. Sea ice is also a critical habitat for female polar bears in autumn, when they prepare to enter their winter birthing dens (Derocher et al. 2011). The timing of sea-ice formation and melt near Hopen has varied substantially over time, reflecting its location near the southern edge of sea-ice extent in the Barents Sea (Shapiro et al. 2003). A trend towards later arrival of sea ice has been observed at Hopen, coinciding with a reduction in sea-ice thickness observed over the last four decades (Gerland et al. 2008). The arrival of sea ice at Hopen shifted from late October to mid-December during the period from 1979 to 2010. Derocher et al. (2011) showed that fewer maternity dens were found on Hopen in years when sea ice arrived later in the autumn. If sea ice formed too late, no dens were found. Further, later arrival of sea ice in autumn was correlated with lower body mass of adult females and their cubs at den emergence in the spring, suggesting that recent environmental conditions have negatively affected female condition. Body mass is an indication of energy stores (Molnár et al. 2009) that are critical for supporting female polar bears during the denning period, when energy is required for maternal maintenance, gestation and nursing (Watts \& Hansen 1987; Derocher et al. 1993; Molnár et al. 2011). Maternal body mass in spring has been positively correlated with body mass of cubs and with cub survival (Derocher \& Stirling 1996, 1998). The finding that cub mass was lower when the date of arrival of sea ice was later (Derocher et al. 2011) suggests that the timing of the arrival of pregnant females at den areas may impact reproductive success.

After leaving the den, young polar bear cubs are vulnerable to hypothermia if exposed to cold water (Blix \& Lentfer 1979; Aars \& Plumb 2010). The suitability of a maternity denning area for raising cubs is determined in part by the timing of sea-ice arrival and departure as well as the sea ice type and its stability (Freitas et al. 2012). There is reason to believe that the fast-ice habitat has deteriorated around Hopen in recent years, an effect of the generally lower sea-ice concentration and thickness in the area. The reproductive success of females that manage to den on Hopen could be negatively affected if the sea ice departs earlier in spring in the future.

The loss of one maternity denning area may not be a major cause for concern because females are able to den in other areas. However, the loss of habitat is symptomatic of larger ecosystem changes that cumulatively may threaten the persistence of polar bears (Amstrup et al. 2010; Hunter et al. 2010; Molnár et al. 2010; Molnár et al. 2011). Further, the Hopen situation might reflect the situation at other important denning areas in Svalbard where autumn sea ice is necessary for giving pregnant females access to denning habitat (NPI, unpubl. data). Monitoring maternity denning areas at the margin of the polar bear range will be important to better understand how adult female polar bears, and ultimately the species, will respond as sea-ice patterns change.

\section{Anthropogenic disturbance in Svalbard}

Although polar bears are no longer harvested in Norway they are still vulnerable to human impacts (Lunn et al. 2002). Recreational activities, such as tourism and camping, are the source of most polar bear-human encounters in Svalbard. Tourism and the local use of snowmobiles have increased in Svalbard over the last 40 years (Overrein 2002; MOSJ: www.mosj.no/en/influ ence/traffic/snowmobiles.html). To avoid the mountainous terrain, much snowmobile driving in Svalbard occurs on land-fast sea ice. On the ice, polar bears hunt ringed seals (Derocher et al. 2002), and the stable fast-ice habitat is particularly important for females with COYs (Freitas et al. 2012). The sea ice is also a substrate for movement between hunting habitats and denning areas (Mauritzen 2002; Derocher et al. 2011; Andersen et al. 2012; Freitas et al. 2012). 
Increasing human activity in the Arctic makes it important to better understand human disturbance of wildlife in the region. Since studies of disturbance are rarely able to assess effects on survival or reproductive success or other effects at the population level, we will most likely have to depend on studies of effects on behaviour and physiological responses as indicators. Such studies can be valuable if the biology of the species is well understood and one can make plausible interpretations about how these responses link to demographic processes. Another limitation apparent in many disturbance studies is that the effect measured on an individual has a short duration. Cumulative population level effects are difficult to assess in most wild populations, and particularly in a long-lived and highly mobile species such as the polar bear.

Polar bears are highly mobile at large temporal and spatial scales, but when considering small-scale movement behaviour within a limited period of time (such as within a fjord) polar bear movements may be restricted (Andersen et al. 2008; Freitas et al. 2012). Stirling (1974) found that polar bears on the sea ice at Devon Island, Canada, spent most of their time inactive. Andersen $\delta$ Aars (2008) observed polar bears running at least one $\mathrm{km}$ (and up to $5 \mathrm{~km}$ ) when disturbed by snowmobiles, and several bears left the ringed seal breathing holes where they were hunting when vehicles approached. Females with COYs in particular showed strong reactions to this kind of disturbance. We believe that repeated disturbance in this important fast-ice habitat could result in increased energetic stress on the animals during a time when they are rebuilding energy stores that are critical for cub survival. Additionally, polar bears are not adapted to running quickly over extended distances and large individuals in particular overheat rapidly if pursued for long (Øritsland 1970). Such stress could force polar bears to use sub-optimal habitats and spend more time in the water, where they typically take refuge when started. It could also lead to more frequently interrupted hunting situations or suckling/feeding bouts, which could affect body condition and growth of both adults and cubs/ COYs. Tourism and associated disturbance is a potential stressor that can act on a local spatial scale during short periods of the year. Local planning and regulations could significantly reduce the negative effects of tourism if relevant and sufficient knowledge of polar bear ecology is available. In Svalbard, regulations limiting snowmobile traffic in sensitive areas in springtime reduce disturbance of females with cubs that have just emerged from their dens (Andersen \& Aars 2008).

Increased human presence in the Arctic in general and in Svalbard and the Barents Sea specifically may lead to more human-bear conflicts, jeopardizing both bears and people. In several incidents in recent years, campers in polar bear territory have been forced to kill polar bears. As the Arctic becomes an increasingly attractive and less remote place to visit, and skiing and hiking expeditions grow in popularity, local regulations and knowledge are needed to keep polar bears and humans safe.

\section{Polar bear diet in the Barents Sea}

In the first study of polar bear diet in Svalbard, the remains of 52 ringed seals, 10 bearded seals and six harp seals were found in the stomachs of harvested bears (Lønø 1970). Harp seals were only found during summer (JuneAugust) and most bearded seals (9/10) were found in the same period. These findings were similar to the composition of the 114 samples of known prey species found by Derocher et al. (2002): 76\% ringed seal, 15\% bearded seal and $9 \%$ harp seal. Similar to earlier studies, ringed seals are the dominant prey of polar bears numerically. However, results obtained by Lønø (1970) and Derocher et al. (2002) suggest that bearded seals, which are larger than ringed seals, make a significant contribution in terms of biomass to the diet of polar bears in Svalbard and the western Barents Sea (Andersen et al. 1999). In the eastern Barents Sea, a Russian study reported $68 \%$ ringed seal, $22 \%$ walrus (Odobenus rosmarus) and other miscellaneous items in the diet of polar bears (Parovshchikov 1964), perhaps reflecting further geographic variation in the same population. Most information on polar bear diet from the Barents Sea is from spring, but Iversen et al. (2013) reported findings based on scat samples from both spring and summer. Their study showed that polar bears in Svalbard feed on eggs, reindeer (Rangifer tarandus) and vegetation, in addition to seals. Reindeer predation by Svalbard polar bears was also documented by Derocher et al. (2000), and Hedberg et al. (2011) found fatty acids in polar bear milk that indicated that they had fed on reindeer.

The distribution and abundance of marine mammal resources available to polar bears in Svalbard are only partially described. Bearded seals are widely distributed throughout Svalbard and the western Barents Sea (Benjaminsen 1973). Their abundance is uncertain but they may number a few hundred thousand in the North Atlantic (Burns 1981; Kovacs et al. 2009). The size of the ringed seal population in the Svalbard area is unknown but the global population likely numbers in the millions (Reeves 1998; Kovacs et al. 2009). In Svalbard and the western Barents Sea, ringed seals give birth in both land-fast (Smith \& Lydersen 1991) and drifting pack ice (Wiig et al. 1999). Freitas et al. (2012) showed that landfast ice is especially important for female polar bears with 
COYs on account of the combination of a stable substrate and the high density of ringed seal breeding lairs. The Barents Sea harp seal population is approximately 2.2 million animals (Nilssen et al. 2000) and represents a seasonally abundant food source for polar bears. However, harp seals do not usually reach polar bear habitat until April-May and then increase in abundance along the drift ice edge until October, when they return south (Haug et al. 1994; Nordøy et al. 1998).

The annual home range size of adult female polar bears in Svalbard varies greatly, ranging from $185 \mathrm{~km}^{2}$ to $373539 \mathrm{~km}^{2}$ (Mauritzen et al. 2001) and dietary differences were postulated to explain the different space use patterns (Mauritzen et al. 2001). In particular, Mauritzen et al. (2001) suggested that near-shore bears relied more on the land-fast ice and preyed largely on ringed seals during spring, while pelagic bears preyed more on bearded and harp seals over a longer period. This is supported by research by Freitas et al. (2012) and Derocher et al. (2002), who found that ringed seal kills were most numerous in land-fast ice areas in spring and bearded and harp seal kills were mainly found in pack-ice areas in summer.

\section{Feeding and contaminant exposure}

Prey composition is an important element in understanding the ecotoxicology of polar bears. If climate change alters the distribution and abundance of prey (Stirling $\&$ Derocher 1993), documentation of the current predation patterns is essential for understanding how exposure to environmental pollutants might vary as a result of climate change (McKinney et al. 2009). Working in Hudson Bay, McKinney et al. (2009) documented how changes in diet, following from changes in sea ice and prey availability, increased the levels of several contaminants in bear tissues. McKinney et al. (2011), McKinney et al. (2013) have also demonstrated how, in East Greenland, polar bear contaminant exposure changed as an effect of dietary shifts.

The release of contaminants into the environment started in Europe from 1850 to 1930. A wide range of man-made pollutants, among them organochlorines, has since been transported by air and ocean currents from southern industrialized areas to the Arctic, (Oehme 1991; Barrie et al. 1992; De March et al. 1998). These compounds are highly lipophilic and resistant to biological degradation; they accumulate in the marine environment and biomagnify up food chains (Muir et al. 1988; Barrie et al. 1992). Arctic organisms are adapted to dealing with short periods of high production during which lipid energy stores are built up, resulting in high dependence on fat at most trophic levels (Barrie et al. 1992). Polar bears have the capacity to metabolize several organic pollutants (Letcher et al. 2000), but the metabolites resulting from this process are believed to have an even more negative effect than the original compounds (Cheek et al. 1999; Marchesini et al. 2008; Gutleb et al. 2010).

\section{PCB contamination}

PCBs were first identified in polar bears in the 1970s (Bowes \& Jonkel 1975). Svalbard polar bears have shown PCB levels comparable to those found in ringed seals from the Baltic Sea, where reproductive disorders were reported (Norheim et al. 1992; Olsson et al. 1992; Bernhoft et al. 1997). In Svalbard polar bears, a possible immunotoxic effect (Bernhoft et al. 2000) and negative association between organochlorines and retinol and thyroid hormones have been reported (Skaare et al. 2000). Studies indicate that organic pollutants have a negative effect on immune response and metabolism in polar bears (Lie et al. 2004, 2005; Braathen et al. 2004; Villanger et al. 2011). Contaminants in polar bears have been studied in most parts of the species range (Norstrom et al. 1998; Verreault et al. 2005; Muir et al. 2006; Mckinney et al. 2011). However, limited data from most parts of the Russian Arctic have precluded an understanding of circumpolar PCB patterns.

Andersen et al. (2001) demonstrated regional variation in PCB contamination in polar bear blood between the European, Russian and western North American Arctic regions. They found $\mathrm{PCB}$ levels to be highest in the western part of the Russian Arctic, and that the relative contribution of the low-chlorinated congeners (PCBs with few chlorine atoms, less toxic) increases, while the higher chlorinated congeners (PCBs with higher number of chlorine atoms, more toxic) decrease, from west to east. Different congener patterns between areas indicate that sources of PCB are different. The study showed that the proportion of the PCB congeners 118 and 156-the most acutely toxic congeners in this study-was higher in the Chukchi Sea compared to Svalbard.

Andersen et al. (2001) suggested that the variation observed in their study is due to polar bears facing different PCB exposure between the regions, something that can be caused by heavier pollution in some areas compared to others, but also by differences in the food webs polar bears rely on. Variation in levels and patterns of various pollutants found in polar bear tissue can be explained by regional prey differences or changes in the diet, as was demonstrated for Hudson Bay polar bears (Mckinney et al. 2009). Satellite tracking of individuals has shown that polar bears in the Kara and Laptev seas 
spend considerable amounts of time in multi-year ice (Belikov et al. 1998). This is also the case for parts of the population in Svalbard and Franz Josef Land (Wiig 1995). Regional differences in the structure of the ice-associated food webs may cause higher levels of contaminants high in the food web in one area compared to another. Andersen et al. (2001) based their study on analyses of blood samples from polar bears captured in five different geographic regions. Though all the bears were females captured in spring, there were differences in age, body condition and reproductive status at capture. Females emerging from dens with young cubs are very lean (Derocher \& Stirling 1998), while others who have lost their cubs or have older cubs start feeding earlier and may be in better condition. Both long- and short-term differences in feeding history (and therefore body condition) presumably influence the concentrations and patterns of organochlorines, which makes it difficult to draw conclusions from the analysis of blood samples, which reflect recent food intake (Lydersen et al. 2002). In addition, females with offspring can shed PCBs through milk, also complicating interpretation of the results of contaminant analyses (Bernhoft et al. 1997; Polischuk 1999; Bytingsvik et al. 2012). Movement behaviour further complicates the issue. For example, Olsen et al. (2003) explained differences in contaminant levels as a result of varying activity seen in small versus large home range sizes in Barents Sea polar bears.

\section{Radionuclide contamination}

Organic pollutants are accumulated in fatty tissues, whereas other groups of contaminants, such as radionuclides, use other pathways but nevertheless accumulate in top predators (in muscle and bone tissue), although less effectively than organic pollutants. The tendency for Arctic marine food chains to depend on benthic and seaice associated systems provides an efficient mechanism for biomagnification of contaminants and, in combination with the longevity of marine mammals, this results in high uptake rates of radionuclides (e.g., Pentreath et al. 1982; Aarkrog et al. 1997; Brown et al. 1999; Carroll et al. 2002).

The anthropogenic radionuclide caesium-137 ( $\left.{ }^{137} \mathrm{Cs}\right)$ makes its way into the Arctic marine environment via global fall-out from atmospheric weapon testing, discharges from European reprocessing and power facilities and fall-out from the Chernobyl accident in 1986. The low ${ }^{137} \mathrm{Cs}$ levels observed in the marine mammals studied by Andersen et al. (2006) reflect the low ${ }^{137}$ Cs activity in sea water in the European Arctic following the reduction in discharges from reprocessing facilities at Sellafield, UK, in the mid-1970s. Recently reported
${ }^{137} \mathrm{Cs}$ activities in sea water from the study area ranged from 2.0 to $3.4 \mathrm{~Bq} / \mathrm{m}^{3}$, compared to peak values of 20-45 Bq $/ \mathrm{m}^{3}$ for the Svalbard area and Barents Sea in the 1980s (Hallstadius et al. 1982; Kershaw and Baxter 1995; Strand et al. 2002). Numerous local sources of potential radionuclide contamination are known in the region, for example, nuclear reactor dump sites and atmospheric nuclear bomb testing sites on Novaya Zemlya. It appears from the data reported by Andersen et al. (2006) that these potential sources have had little impact on marine mammals in the European Arctic.

In general, pollution acts across large temporal and spatial scales, potentially having negative effects on polar bear reproduction and survival in several populations. The decrease in PCBs found in Arctic biota following the ban shows how positive results can be achieved (Wolkers et al. 2008; Dietz, Rigét et al. 2013; Rigét et al. 2013). However, relatively new compounds - for example brominated flame retardants and perfluoroalkyl contaminantsare being detected in polar bear tissues, calling for new research and management initiatives. While most sources of organic pollutants are found outside the Arctic, and output is continuous but slow, there are many sources of radioactive contamination within the Arctic, with the potential for acute and significant contamination.

\section{Multiple stressors and future monitoring and management}

\section{Stressors and cumulative effects}

A stressor has been defined as a variable (biotic or abiotic) that adversely affects individual physiology or population performance and therefore has fitness consequences (Barrett et al. 1976; Vinebrooke et al. 2004). Stressors can be both natural and anthropogenic, and they often interact to produce a combined impact.

Sea-ice changes, disturbance by people and pollution, are threats to polar bears in the Svalbard and Barents Sea area that act on different spatial and temporal scales. Consequently, they are linked to different aspects of polar bear population biology as stressors. Jenssen pointed out that pollutants with endocrine-disruptive properties are the second most serious anthropogenic threat in the Arctic, after climate change, and that the combination of these two stressors may be a "worst-case combination for Arctic marine mammals and birds" (Jenssen 2006: 79). Dietz, Basu et al. (2013) stated that different contaminants (for example, various POPs and heavy metals) can act together, making it difficult to determine the effect of an individual compound in free-ranging animals. Further, they noted that confounding factors such as 
age, sex, reproductive status, body condition and diseases or other stressors further complicates analyses. They suggested nevertheless that increasing trends of mercury $(\mathrm{Hg})$ in polar bears from north-east Canada and East Greenland might represent a health risk to the most susceptible animals when stress from climate change, shifts in pathogen organisms, decreased access to food and other contaminants are simultaneously taken into account (Dietz, Basu et al. 2013).

It has been documented that contaminants have negative effects on thyroid hormones, sex steroid homeostasis and the immune system of marine mammals, including polar bears (Haave et al. 2003; Olsen et al. 2003; Oskam et al. 2003; Braathen et al. 2004; Lie et al. 2004, 2005; Oskam et al. 2004; Letcher et al. 2010). Acting on quite different scales, sea-ice changes and human disturbance may reduce access to food or increase energy expenditure by making hunting less effective (including by reducing prey) or increasing the distances polar bears need to walk or swim. In combination with generally weaker health, the net effect of the stressors might affect survival significantly, especially for very young or old animals. This is suggested by a study in Hudson Bay, where a longer ice-free period lowered survival in these two age groups (Regehr et al. 2007). The Hudson Bay population is not considered to be significantly impacted by pollution and disturbance by humans is limited to the period when bears are fasting on land. However, there is reason to believe that there will be an increase in disturbance and human-bear conflicts as climate change progresses, in this population and elsewhere in the Arctic.

Lowered survival as a result of sea-ice changes was also found in polar bears in the southern Beaufort Sea (Regehr et al. 2010). For Svalbard, the effect of sea-ice reduction on survival has not yet been examined. However, contamination has been suggested as a possible explanation for the slow population recovery after the heavy harvest stopped in 1973 (Derocher 2005). In addition, polar bear habitat in this region is projected to be significantly reduced in the decades to come, which will probably lead to decreasing population size (Amstrup et al. 2008; Durner et al. 2009; Amstrup et al. 2010). During recent years in Svalbard, ringed seal pup production, which takes place on both drift and land-fast ice (Smith $\delta$ Lydersen 1991), has been very low in several important breeding fjords (Kovacs et al. 2011). As the most nutritionally stressed group of bears in spring, female polar bears with small cubs will likely be particularly vulnerable to the loss of this potential prey (Watts \& Hansen 1987; Atkinson \& Ramsay 1995). Since fat-soluble contaminants are released into blood circulation when stored fat is metabolized, high levels of contaminants are carried to the mothers' vital organs during the period when the pregnant female is fasting in the den and during the first months of lactation, which causes transfer of pollutants first to the foetuses in utero and after birth to the cubs through the milk (Polischuk et al. 2002). The negative effects of pollution and less sea-ice in the Barents Sea will act on polar bears synergistically if the combined effect is greater than one would expect by adding up the effects of the individual stressors (Derocher 2005; Jenssen 2006).

Although relatively little research has been conducted on the subject, it is expected that climate change may increase levels - and diversity-of pathogens in the Arctic (Bradley et al. 2005; Burek et al. 2008), which would add another stressor to already struggling polar bears (Derocher et al. 2004; Molnár et al. 2010). Baseline levels of occurrence of pathogens such as Brucella, Toxoplasma and viruses have been documented in polar bears from the Svalbard area (Tryland et al. 2001; Tryland et al. 2005; Oksanen et al. 2009; Åsbakk et al. 2010; Jensen et al. 2010), but long-term monitoring and the effects of disease in a multi-stressor analysis have not yet been established.

\section{Monitoring and management}

The key feature of the recently introduced concept of adaptive monitoring is that the monitoring process should evolve as new knowledge and questions emerge (Lindenmayer \& Likens 2009). This is exemplified by polar bear population monitoring. Our knowledge about important impacts on this species has changed through time. Recently, the need to better understand the population level effects of a range of stressors has been highlighted (Vongraven \& Peacock 2011; Vongraven et al. 2012). The Barents Sea polar bear population is monitored through MOSJ, which constantly evaluates the choice of monitoring parameters on the basis of findings produced by ongoing research. When research found that sea-ice conditions limited denning opportunities in a traditionally important denning area (Derocher et al. 2011) monitoring of the sea-ice habitat surrounding the main denning areas was initiated. Another example is the ongoing screening for new pollutants in polar bears in the region, which feeds into international processes to ban the release of certain industrial compounds.

A corollary of adaptive monitoring is adaptive management (Lindenmayer \& Likens 2009; Vongraven et al. 2012): when changes occur in a population, management regimes should change accordingly. It is important to recognize that population changes might be rapid as 
thresholds are crossed, and that plans for how to deal with such changes should be made early (Derocher et al. 2013). Management aims must be re-evaluated in light of new threats and information. For some subpopulations, sustainable harvest is the management goal; for others it is conservation of the species. Maintaining that polar bears are not in danger of extinction, some stake-holders argue that powerful conservation measures, such as lowered quotas or total protection of animals and their habitats, are not needed and that good resource management is sufficient to ensure their survival (Wiig 2005; Vongraven 2009; Vongraven et al. 2012). This may be true for some polar bear populations, but the status of others is far more uncertain. Some populations are declining (Regehr et al. 2007; Hunter et al. 2010; Regehr et al. 2010) and for others data is unavailable (Obbard et al. 2010), indicating that a more careful conservation approach should be taken. The Barents Sea population is one of few populations that is totally protected andwithin Norwegian territorial waters - some habitat crucial for polar bears is under varying degrees of protection. In this population, the precautionary principle has been used as a conservation tool.

As overharvesting and poaching were the main conservation concerns when the work on the Polar Bear Agreement was initiated in the 1960s (Anonymous 1966; Prestrud \& Stirling 1994), quota systems were implemented for some populations and total protection for others (Prestrud \& Stirling 1994). Ongoing and future large-scale habitat losses, in combination with threats such as pollution and human development, are different kinds of challenges that require a broad management approach. While the rapid climate change of the last century is generally understood to be mainly anthropogenic (Core Writing Team et al. 2007), the reversibility of climate change is being debated. Amstrup et al. (2010) argued that a significant reduction in the emission of $\mathrm{CO}_{2}$ to the atmosphere could slow the rate of sea-ice loss, benefitting polar bears.

\section{Conservation}

It has been suggested that only strict conservation measures, requiring coordinated effort from all Range States, will secure the survival of the species (Vongraven $\delta$ Peacock 2011; Vongraven et al. 2012). This is consistent with advice given to the international community with regard to conservation of mammals globally. Rondinini et al. (2011) identified key elements for a successful largescale conservation strategy for mammals to include an institution with recognized authority, clear goals and objectives as well as relevant species data, a priority list and well developed indicators. Proposing international cooperation around the Convention on Biological Diversity as a possible starting point for a new global initiative for the conservation of mammals, Rondinini et al. (2011) also suggest that an expanded version of the IUCN Red List would be a suitable future tool. Wilson and co-workers point out that one of the main challenges in mammal conservation is prioritizing what to focus on, since "we cannot do everything, everywhere, all the time" (Wilson et al. 2011: 2670). However, Rondinini et al. (2011) stress the urgency of a global mammal conservation strategy in spite of significant knowledge gaps. Recent international initiatives to improve knowledge and monitoring of polar bear populations throughout the range of the species (e.g., Anonymous 2009; Vongraven et al. 2012) are in line with these views.

\section{Conclusions}

The biological traits that make polar bears well adapted to the Arctic environment are problematic in the context of encounters with human activity, pollution and significant changes to sea-ice habitat. We have described how polar bears in Svalbard have been negatively affected by human activity in the last century and how these threats have changed through time. The clear linkages between population biology and current anthropogenic threats give reason to believe that the combination of several stressors is having significant negative effects on polar bears. However, the processes involved and the population level effects are not well understood. An international action plan for polar bears was finalized in September 2015 (Polar Bear Range States 2015) and a comprehensive monitoring programme that aims to give us an understanding of the consequences of multiple stressors has been recommended by an international expert group (Vongraven et al. 2012). Norway is obliged to manage the Norwegian polar bears using the best available scientific data, as stated by Article VII of the Agreement, and should therefore follow the advice given by the group. Norwegian authorities completed a national action plan for polar bears in 2013, addressing how the future management of the species requires relevant research and monitoring through increased scientific effort in the Barents Sea. The plan outlines the main areas of interest and concern in the Barents Sea population: the effects of habitat change, contamination, acute pollution and crisis handling, disturbance and stress due to human activities and human-bear conflicts. The plan also emphasizes Norwegian responsibilities regarding cooperation with neighbouring countries and the international component of polar bear research and management. 


\section{Acknowledgements}

We would like to thank Øystein Wiig, Andrew E. Derocher, Dag Vongraven, Kit M. Kovacs, Erik W. Born Kristin Laidre and two reviewers for valuable comments on an earlier version of this manuscript. We would also like to thank Anders Skoglund for creating the maps.

\section{References}

Aarkrog A., Baxter M.S., Bettencourt A.O., Bojanowski R., Bologa A., Charmasson S., Cunha I., Delfanti R., Duran E., Holm E., Jeffree R., Livingston H., Mahapanyawong H., Nies S., Osvath I., Pingyu L., Povinec P., Sanchez A., Smith J. \& Swift D. 1997. A comparison of doses from ${ }^{137} \mathrm{Cs}$ and

${ }^{210} \mathrm{Po}$ in marine food: a major international study. Journal of Environmental Radioactivity 34, 69-90.

Aars J., Marques T.A., Buckland S.T., Andersen M., Belikov S., Boltunov A. \& Wiig Ø. 2009. Estimating the Barents Sea polar bear subpopulation size. Marine Mammal Science 25, 35-52.

Aars J. \& Plumb A. 2010. Polar bear cubs may reduce chilling from icy water by sitting on mother's back. Polar Biology 33, 557-559.

Amstrup S.C. 1993. Human disturbance of denning polar bears in Alaska. Arctic 46, 246-250.

Amstrup S.C., DeWeaver E.T., Douglas D.C., Marcot B.G., Durner G.M., Bitz C.M. \& Bailey D.A. 2010. Greenhouse gas mitigation can reduce sea-ice loss and increase polar bear persistence. Nature 468, 955-958.

Amstrup S.C. \& Gardner C. 1994. Polar bear maternity denning in the Beaufort Sea. Journal of Wildlife Management 58, $1-10$.

Amstrup S.C., Marcot B.G. \& Douglas D.C. 2008. A Bayesian network approach to forecasting the 21 st century worldwide status of polar bears. In E.T. DeWeaver et al. (eds.): Arctic sea ice decline: observations, projections, mechanisms, and implications. Pp. 213-268. Washington, DC: American Geophysical Union.

Andersen M. \& Aars J. 2008. Short-term behavioural response of polar bears to disturbance by snowmobiles. Polar Biology 31, 501-507.

Andersen M., Derocher A.E., Wiig Ø. \& Aars J. 2008. Movements of two Svalbard polar bears recorded using geographical positioning system satellite transmitters. Polar Biology 31, 905-911.

Andersen M., Derocher A.E., Wiig Ø. \& Aars J. 2012. Polar bear (Ursus maritimus) maternity den distribution in Svalbard, Norway. Polar Biology 35, 499-508.

Andersen M., Gwynn J.P., Dowdall M. \& Lydersen C. 2006. Radiocaesium in marine mammals from Svalbard, the Barents Sea and the North Greenland Sea. Science of the Total Environment 363, 87-94.

Andersen M., Hjelset A.M., Gjertz I., Lydersen C. \& Gulliksen B. 1999. Growth, age at sexual maturity and condition in bearded seals (Erignathus barbatus) from Svalbard, Norway. Polar Biology 21, 179-186.
Andersen M., Lie E., Derocher A.E., Belikov S.E., Bernhoft A., Boltunov A.N., Garner G.W., Skaare J.U. \& Wiig Ø. 2001. Geographic variation of PCB congeners in polar bears (Ursus maritimus), from Svalbard to the Chukchi Sea. Polar Biology 24, 231-238.

Anonymous 1966. Proceedings of the first international scientific meeting on the polar bear at Fairbanks, Alaska. 6-10 September 1965. Washington, DC: Bureau of Sport Fisheries and Wildlife, US Department of the Interior, and University of Alaska.

Anonymous 2009. Meeting of the parties to the 1973 Agreement on the Conservation of Polar Bears. 17-19 March 2009, Tromso, Norway. Outcome of meeting. Accessed on the internet at http://pbsg.npolar.no/export/sites/pbsg/en/docs/Outcome_ MOP2009.pdf on 31 March 2016

Anonymous 2010. Meld. St. 10 (2010-2011). Melding til Stortinget. Oppdatering av forvaltningsplanen for det marine miljø i Barentshavet og havomradene utenfor Lofoten. (Meld. St. 10 [2010-2011]. Report to the Storting [white paper]. First update of the Integrated Management Plan for the Marine Environment of the Barents Sea-Lofoten Area.) Oslo: Norwegian Ministry of the Environment.

Arthur S.M., Manly B.F.J., McDonald L.L. \& Garner G.W. 1996. Assessing habitat selection when availability changes. Ecology 77, 215-227.

Åsbakk K., Aars J., Derocher A.E., Wiig Ø., Oksanen A., Born E.W., Dietz R., Sonne C., Godfroid J. \& Kapel C.M.O. 2010. Serosurvey for Trichinella in polar bears (Ursus maritimus) from Svalbard and the Barents Sea. Veterinary Parasitology 172, 256-263.

Atkinson S.N. \& Ramsay M.A. 1995. The effects of prolonged fasting on the body-composition and reproductive success of female polar bears (Ursus maritimus). Functional Ecology 9, 559-567.

Barrett G.W., Vandyne G.M. \& Odum E.P. 1976. Stress ecology. Bioscience 26, 192-194.

Barrie L.A., Gregor D., Hargrave B., Lake R., Sherer R., Tracey B. \& Bidleman T. 1992. Arctic contaminants: sources, occurrence and pathways. Science of the Total Environment 122, 1-74.

Belikov S.E. 1980. Distribution and structure of dens of female polar bears in Wrangel Island. Bears. Their Biology and Management 4, 117-118.

Belikov S.E., Garner G.W., Wiig Ø., Boltunov A.N. \& Gorbunov Y.A. 1998. Polar bears of the Zevernaya Zemlya Archipelago of the Russian Arctic. Ursus 10, 33-40.

Benjaminsen T. 1973. Age determination and the growth and age distribution from cementum growth layers of bearded seals at Svalbard. Fiskeridirektoratets Skrifter Serie Havundersøkelser 16, 159-170.

Bernhoft A., Skaare J.U., Wiig Ø., Derocher A.E. \& Larsen H.J.S. 2000. Possible immunotoxic effects of organochlorines in polar bears (Ursus maritimus) at Svalbard. Journal of Toxicology and Environmental Health 59, 561-574.

Bernhoft A., Wiig Ø. \& Skaare J.U. 1997. Organochlorines in polar bears (Ursus maritimus) at Svalbard. Environmental Pollution 95, 159-175. 
Blaszczyk M., Jania J.A. \& Hagen J.O. 2009. Tidewater glaciers of Svalbard: recent changes and estimates of calving fluxes. Polish Polar Research 30, 85-142.

Blix A.S. \& Lentfer J.W. 1979. Modes of thermal protection in polar bear cubs - at birth and on emergence from the den American Journal of Physiology 236, 67-74.

Borchers D.L., Buckland S.T. \& Zucchini W. 2002. Estimating animal abundance. Closed populations. London: Springer.

Bowes G.W. \& Jonkel C.J. 1975. Presence and distribution of polychlorinated biphenyls (PCB) in Arctic and Subarctic marine food chains. Journal of the Fisheries Research Board of Canada 32, 281-286.

Braathen M., Derocher A.E., Wiig Ø., Sørmo E.G., Lie E., Skaare J.U. \& Jenssen B.M. 2004. Relationships between PCBs and thyroid hormones and retinol in female and male polar bears. Environmental Health Perspectives 112, 826-833.

Bradley M.J., Kutz S.J., Jenkins E. \& O'Hara T.M. 2005. The potential impact of climate change on infectious diseases of Arctic fauna. International Journal of Circumpolar Health 64, 468-477.

Brown J.E., Kolstad A.K., Brungot A.L., Lind B., Rudjord A.L., Strand P. \& Føyn L. 1999. Levels of ${ }^{99}$ Tc in seawater and biota samples from Norwegian coastal waters and adjacent seas. Marine Pollution Bulletin 38, 560-571.

Buckland S.T., Anderson D.R., Burnham K.P., Laake J.L., Borchers D.L. \& Thomas L. (eds.) 2004. Advanced distance sampling. Oxford: Oxford University Press.

Burek K.A., Gulland F.M.D. \& O'Hara T.M. 2008. Effects of climate change on Arctic marine mammal health. Ecological Applications 18, 126-134.

Burns J.J. 1981. Bearded seal Erignathus barbatus Erxleben, 1777. In S.H. Ridgway \& R.J. Harrison (eds.): Handbook of marine mammals. Vol. 2. Seals. Pp. 145-170. London: Academic Press.

Bytingsvik J., Lie E., Aars J., Derocher A.E., Wiig Ø. \& Jenssen B.M. 2012. PCBs and OH-PCBs in polar bear mother-cub pairs: a comparative study based on plasma levels in 1998 and 2008. Science of the Total Environment 417, 117-128.

Carroll J., Wolkers H., Andersen M. \& Rissanen K. 2002. Bioaccumulation of radiocaesium in Arctic seals. Marine Pollution Bulletin 44, 1366-1371.

Cheek A.O., Kow K., Chen J. \& McLachlan J.A. 1999. Potential mechanisms of thyroid disruption in humans: interaction of organochlorine compounds with thyroid receptor, transthyretin, and thyroid-binding globulin. Environmental Health Perspectives 107, 273-278.

Comiso J.C. 2002. A rapidly declining perennial sea ice cover in the Arctic. Geophysical Research Letter 29, L1956, doi: 10.1029/2002GL015650.

Comiso J.C., Parkinson C.L., Gersten R. \& Stock L. 2008 Accelerated decline in the Arctic sea ice cover. Geophysical Research Letter 35, L01703, doi: 10.1029/2007GL031972.

Core Writing Team, Pachauri R.K. \& Reisinger A. (eds.) 2007. Climate change 2007. Synthesis report. Contribution of Working Groups I, II and III to the fourth assessment report of the Intergovernmental Panel on Climate Change. Geneva: Intergovernmental Panel on Climate Change.
De March B.G.E., de Wit C.A., Muir C.G., Braune B.M., Gregor D.J., Norstrom R.J., Olsson M., Skaare J.U. \& Stange K. 1998. Persistent organic pollutants. In S.J. Wilson et al. (eds.): AMAP assessment report: Arctic pollution issues. Pp. 183-371. Oslo: Arctic Monitoring and Assessment Programme.

DeMaster D.P., Kingsley M.C.P. \& Stirling I. 1980. A multiple mark and recapture estimate applied to polar bears. Canadian Journal of Zoology 58, 633-638.

Derocher A.E. 2005. Population ecology of polar bears at Svalbard, Norway. Population Ecology 47, 267-275.

Derocher A.E., Aars J., Amstrup S.C., Cutting A., Lunn N.J., Molnar P.K., Obbard M.E., Stirling I., Thiemann G.W., Vongraven D., Wiig Ø. \& York G. 2013. Rapid ecosystem change and polar bear conservation. Conservation Letters 6 , $368-375$.

Derocher A.E., Andersen M., Wiig Ø., Aars J., Hansen E. $\delta$ Biuw M. 2011. Sea ice and polar bear den ecology at Hopen Island, Svalbard. Marine Ecology Progress Series 441, 273-279.

Derocher A.E., Andriashek D. \& Arnould J.P.Y. 1993. Aspects of milk composition and lactation in polar bears. Canadian Journal of Zoology 71, 561-567.

Derocher A.E., Lunn N.J. \& Stirling I. 2004. Polar bears in a warming climate. Integrative and Comparative Biology 44, $163-176$

Derocher A.E. \& Stirling I. 1990. Observations of aggregating behaviour in adult male polar bears (Ursus maritimus). Canadian Journal of Zoology 68, 1390-1394.

Derocher A.E. \& Stirling I. 1996. Aspects of survival in juvenile polar bears. Canadian Journal of Zoology 74, 1246-1252.

Derocher A.E. \& Stirling I. 1998. Maternal investment and factors affecting offspring size in polar bears (Ursus maritimus). Journal of Zoology 245, 253-260.

Derocher A.E., Wiig Ø. \& Andersen M. 2002. Diet composition of polar bears in Svalbard and the western Barents Sea. Polar Biology 25, 448-452.

Derocher A.E., Wiig Ø. \& Bangjord G. 2000. Predation of Svalbard reindeer by polar bears. Polar Biology 23, 675-678.

Derocher A.E., Wolkers H., Colborn T., Schlabach M., Larsen T.S. \& Wiig Ø. 2003. Contaminants in Svalbard polar bear samples archived since 1967 and possible population level effects. Science of the Total Environment 301, 163-174.

Dietz R., Basu N., Braune B., O'Hara T., Scheuhammer T., Sonne C., Andersen M., Andreasen C., Andriashek D., Asmund G., Aubail A., Baagøe H., Born E.W., Chan H.M., Derocher A.E., Grandjean P., Knott K., Kirkegaard M., Lunn N., Messier F., Obbard M., Olsen M.T., Peacock E., Renzoni A., Rigét F.F., Skaare J.U., Stern G., Stirling I., Taylor M., Wiig Ø., Wilson S. \& Aars J. 2013. What are the toxicological effects of mercury in Arctic biota? Science of the Total Environment 443, 775-790.

Dietz R., Rigét F.F., Sonne C., Born E.W., Bechshøft T., McKinney M.A. \& Letcher R.J. 2013. Three decades (19832010) of contaminant trends in East Greenland polar bears (Ursus maritimus). Part 1. Legacy organochlorine contaminants. Environment International 59, 485-493. 
Durner G.M., Douglas D.C., Nielson R.M., Amstrup S.C., Mcdonald T.L., Stirling I., Mauritzen M., Born E.W., Wiig Ø., DeWeaver E., Serreze M.C., Belikov S.E., Holland M.M., Maslanik J., Aars J., Bailey D.A. \& Derocher A.E. 2009. Predicting 21 st century polar bear habitat distribution from global climate models. Ecological Monographs 79, 25-58.

Evans T.J., Fischbach A., Schliebe S., Manly B., Kalxdorff S. \& York G. 2003. Polar bear aerial surveys in the eastern Chukchi Sea: a pilot study. Arctic 56, 359-366.

Ferguson S., Taylor M., Born E., Rosing-Asvid A. \& Messier F. 2001. Activity and movement patterns of polar bears inhabiting consolidated versus active pack ice. Arctic 54, 49-54.

Ferguson S., Taylor M., Rosing-Asvid A., Born E. \& Messier F. 2000. Relationships between denning of polar bears and conditions of sea ice. Journal of Mammalogy 81, 1118-1127.

Ferguson S.H., Taylor M.K. \& Messier F. 2000. Influence of sea ice dynamics on habitat selection by polar bears. Ecology 81, 761-772.

Fischbach A.S., Amstrup S.C. \& Douglas D.C. 2007. Landward and eastward shift of Alaskan polar bear denning associated with recent sea ice changes. Polar Biology 30, 1395-1405.

Frair J.L., Nielsen S.E., Merrill E.H., Lele S.R., Boyce M.S., Munro R.H.M., Stenhouse G.B. \& Beyer H.L. 2004. Removing GPS collar bias in habitat selection studies. Journal of Applied Ecology 41, 201-212.

Freitas C., Kovacs K.M., Andersen M., Aars J., Sandven S., Mauritzen M., Pavlova O. \& Lydersen C. 2012. Importance of fast ice and glacier fronts for female polar bears and their cubs during spring in Svalbard, Norway. Marine Ecology Progress Series 447, 289-304.

Furgal C.M., Innes S. \& Kovacs K.M. 1996. Characteristics of ringed seal, Phoca hispida, subnivean structures and breeding habitat and their effects on predation. Canadian Journal of Zoology 74, 858-874.

Gau R.J., Mulders R., Ciarniello L.J., Heard D.C., Chetkiewicz C.B., Boyce M., Munro R., Stenhouse G., Chruszcz B., Gibeau M.L., Milakovic B. \& Parker K.L. 2004. Uncontrolled field performance of Televilt GPS-simplex (Tm) collars on grizzly bears in western and northern Canada. Wildlife Society Bulletin 32, 693-701.

Gerland S., Gascard J.C., Ivanov B., Nielsen C.P., Nilsen E., Pavlova O., Leu E., Tverberg V. \& Barrault S. 2007. Fast ice evolution in Kongsfjorden compared with other Svalbard fjords. Extended abstract. In R. Azzolini (ed.): 8th Ny-Ålesund seminar. 16-17 October 2007. Cambridge, UK. Polarnet Technical Report. Pp. 44-46. Rome: Earth and Environment Department, National Research Council.

Gerland S. \& Hall R. 2006. Variability of fast-ice thickness in Spitsbergen fjords. Annals of Glaciology 44, 231-239.

Gerland S., Renner A.H.H., Godtliebsen F., Divine D. \& Løyning T.B. 2008. Decrease of sea ice thickness at Hopen, Barents Sea, during 1966-2007. Geophysical Research Letter 35, L06501, doi: 10.1029/2007GL032716.

Gutleb A.C., Cenijn P., van Velzen M., Lie E., Ropstad E., Skaare J.U., Malmberg T., Bergman A., Gabrielsen G.W. \& Legler J. 2010. In vitro assay shows that PCB metabolites completely saturate thyroid hormone transport capacity in blood of wild polar bears (Ursus maritimus). Environmental Science $\theta$ Technology 44, 3149-3154.

Haarpaintner J., Haugan P.M. \& Gascard J.C. 2001. Interannual variability of the Storfjorden (Svalbard) ice cover and ice production observed by ERS-2 SAR. Annals of Glaciology 33, 430-436.

Haave M., Ropstad E., Derocher A.E., Lie E., Dahl E., Wiig Ø., Skaare J.U. \& Jenssen B.M. 2003. Polychlorinated biphenyls and reproductive hormones in female polar bears at Svalbard. Environmental Health Perspectives 111, 431-436.

Hallstadius L., Holm E., Persson B., Aarkrog A. \& Nilsson K. 1982. ${ }^{137} \mathrm{Cs}$ in the Svalbard area. In: Third international symposium. Radiological protection-advances in theory and practice. Proceedings. Vol. 2. Pp. 500-505. Reading: Society for Radiological Protection.

Harington C.R. 1965. The life and status of the polar bear. Oryx 8, 169-176.

Harington C.R. 1968. Denning habits of the polar bear (Ursus maritimus Phipps). Canadian Wildlife Service Report Series 5, 1-30.

Haug T., Nilssen K.T., Øien N. \& Potelov V. 1994. Seasonal distribution of harp seals (Phoca groenlandica) in the Barents Sea. Polar Research 13, 163-172.

Hedberg G.E., Derocher A.E., Andersen M., Rogers Q.R., DePeters E.J., Lonnerdal B., Mazzaro L., Chesney R.W. \& Hollis B. 2011. Milk composition in free-ranging polar bears (Ursus maritimus) as a model for captive rearing milk formula. Zoo Biology 30, 550-565.

Heggberget T., Bjørge A., Swenson J.E., Syvertsen P.O., Wiig Ø. \& Øien N. 2006. Pattedyr. (Mammalia.) In J.A. Kålås et al. (eds.): Norsk Rødliste 2006. (2006 Norwegian Red List.) Pp. 365-372. Trondheim: Artsdatabanken.

Houghton J.T., Ding Y., Griggs D.J., Noguer M., van der Linden P.J., Dai X., Maskell K. \& Johnson C.A. (eds.) 2001. Climate change 2001. The scientific basis. Contribution of Working Group I to the third assessment report of the Intergovernmental Panel on Climate Change. Cambridge: Cambridge University Press.

Høyland K.V. 2009. Ice thickness, growth and salinity in Van Mijenfjorden, Svalbard, Norway. Polar Research 28, 339-352.

Hunter C.M., Caswell H., Runge M.C., Regehr E.V., Amstrup S.C. \& Stirling I. 2010. Climate change threatens polar bear populations: a stochastic demographic analysis. Ecology 91, 2883-2897.

Isaksen K. \& Wiig Ø. 1995. Seasonal distribution of harbour seals, bearded seals, white whales and polar bears in the Barents Sea. Norsk Polarinstitutt Meddelelser 136, 47-59.

Iversen M., Aars J., Haug T., Alsos I.G., Lydersen C., Bachmann L. \& Kovacs K.M. 2013. The diet of polar bears (Ursus maritimus) from Svalbard, Norway, inferred from scat analysis. Polar Biology 36, 561-571.

Jenssen B.M. 2006. Endocrine-disrupting chemicals and climate change: a worst-case combination for Arctic marine mammals and birds? Environmental Health Perspectives 114, $76-80$.

Jensen S.K., Aars J., Lydersen C., Kovacs K.M. \& Åsbakk K. 2010. The prevalence of Toxoplasma gondii in polar bears and 
their marine mammal prey: evidence for a marine transmission pathway? Polar Biology 33, 599-606.

Johnson C.J., Heard D.C. \& Parker K.L. 2002. Expectations and realities of GPS animal location collars: results of three years in the field. Wildlife Biology 8, 153-159.

Jonkel C.J. 1970. Some comments on polar bear management. Biological Conservation 2, 115-119.

Jonkel C.J., Kolenosky G.B., Robertson R. \& Russell R.H. 1972. Further notes on the polar denning habits. International Conference on Bear Research and Management 2, $142-158$.

Kershaw P.J. \& Baxter A. 1995. The transfer of reprocessing wastes from north-west Europe to the Arctic. Deep-Sea Research Part II 42, 1413-1448.

Kingsley M.C.S., Stirling I. \& Calvert W. 1985. The distribution and abundance of seals in the Canadian High Arctic, 1980-82. Canadian Journal of Fisheries and Aquatic Science 42, 1189-1210.

Kovacs K.M., Haug T. \& Lydersen C. 2009. Marine mammals in the Barents Sea. In E. Sakshaug et al. (eds.): Ecosystem Barents Sea. Pp. 453-496. Trondheim: Tapir Academic Press.

Kovacs K.M., Lydersen C., Overland J.E. \& Moore S.E. 2011. Impacts of changing sea-ice conditions on Arctic marine mammals. Marine Biodiversity 41, 181-194.

Krafft B.A., Kovacs K.M. \& Lydersen C. 2007. Distribution of sex and age groups of ringed seals, Pusa hispida, in the fastice breeding habitat of Kongsfjorden, Svalbard. Marine Ecology Progress Series 335, 199-206.

Larsen T. 1967. The trapping and study of polar bears, Spitsbergen, 1966. Polar Record 13, 589-593.

Larsen T. 1970. Polar bear Thalarctos maritimus research in Spitsbergen. Oryx 10, 368-372.

Larsen T. 1972. Air and ship census of polar bears in Svalbard (Spitsbergen). Journal of Wildlife Management 36, 562-570.

Larsen T. 1985. Polar bear denning and cub production in Svalbard, Norway. Journal of Wildlife Management 49, 320-326.

Larsen T. 1986. Population biology of the polar bear (Ursus maritimus) in the Svalbard area. Norsk Polarinstitutt Skrifter 184. Oslo: Norwegian Polar Institute.

Larsen T., Jonkel C. \& Vibe C. 1983. Satellite radio-tracking of polar bears between Svalbard and Greenland. International Conference on Bear Research and Management 5, 230-237.

Larsen T.S. \& Stirling I. 2009. The agreement on the conservation of polar bears-its history and future. Report Series 127. Tromsø: Norwegian Polar Institute.

Lentfer J.W. 1969. Polar bear tagging in Alaska, 1968. Polar Record 14, 459-462.

Lentfer J.W. 1975. Polar bear denning on drifting sea ice. Journal of Mammalogy 56, 716-718.

Lentfer J.W. \& Hensel R.J. 1980. Alaskan polar bear denning. In C.J. Martinka \& K.L. McArthur (eds.): Bears - their biology and management. A selection of papers from the Fourth International Conference on Bear Research and Management held at Kalispell, Montana, USA. February 1977. Pp. 101-108. Washington, DC: Bear Biology Association.

Letcher R.J., Bustnes J.O., Dietz R., Jenssen B.M., Jorgensen E.H., Sonne C., Verreault J., Vijayan M.M. \& Gabrielsen
G.W. 2010. Exposure and effects assessment of persistent organohalogen contaminants in Arctic wildlife and fish. Science of the Total Environment 408, 2995-3043.

Letcher R.J., Klasson-Wehler E., Bergman A. \& Paasivirta J. 2000. Methyl sulfone and hydroxylated metabolites of polychlorinated biphenyls. In J. Passivirts (ed.): The handbook of environmental chemistry. Pp. 315-359. Berlin: Springer.

Lie E., Larsen H.J.S., Larsen S., Johnsen G.M., Derocher A.E., Lunn N.J., Norstrom R.J., Wiig Ø. \& Skaare J.U. 2004. Does high organochlorine (OC) exposure impair the resistance to infection in polar bears (Ursus maritimus)? Part I. Effect of OCs on the humoral immunity. Journal of Toxicology and Environmental Health Part A Current Issues 67, 555-582.

Lie E., Larsen H.J.S., Larsen S., Johansen G.M., Derocher A.E., Lunn N.J., Norstrom R.J., Wiig Ø. \& Skaare J.U. 2005. Does high organochlorine (OC) exposure impair the resistance to infection in polar bears (Ursus maritimus)? Part II. Possible effect of OCs on mitogen- and antigen-induced lymphocyte proliferation. Journal of Toxicology and Environmental Health Part A Current Issues 68, 457-484.

Lindenmayer D.B. \& Likens G.E. 2009. Adaptive monitoring: a new paradigm for long-term research and monitoring. Trends in Ecology $\theta$ Evolution 24, 482-486.

Lønø O. 1970. The polar bear (Ursus maritimus Phipps) in the Svalbard area. Norsk Polarinstitutt Skrifter 149. Oslo: Norwegian Polar Institute.

Lunn N.J., Schliebe S. \& Born E.W. 2002. Polar bears. Proceedings of the 13th Working Meeting of the IUCN/SSC Polar Bear Specialist Group, 23-28 June 2001, Nuuk, Greenland. Gland: IUCN Species Survival Commission.

Lydersen C., Wolkers H., Severinsen T., Kleivane L., Nordøy E.S. \& Skaare J.U. 2002. Blood is a poor substrate for monitoring pollution burdens in phocid seals. Science of the Total Environment 292, 193-203.

Marchesini G.R., Meimaridou A., Haasnoot W., Meulenberg E., Albertus F., Mizuguchi M., Takeuchi M., Irth H. \& Murk A.J. 2008. Biosensor discovery of thyroxine transport disrupting chemicals. Toxicology and Applied Pharmacology 232, 150-160.

Mauritzen M. 2002. Patterns and processes in female polar bear space-use. PhD thesis, University of Oslo.

Mauritzen M., Belikov S.E., Boltunov A.N., Derocher A.E., Hansen E., Ims R.A., Wiig Ø. \& Yoccoz N. 2003. Functional responses in polar bear habitat selection. Oikos 100, 112-124.

Mauritzen M., Derocher A.E. \& Wiig Ø. 2001. Space-use strategies of female polar bears in a dynamic sea ice habitat. Canadian Journal of Zoology 79, 1704-1713.

Mauritzen M., Derocher A.E., Wiig Ø., Belikov S.E., Boltunov A., Hansen E. \& Garner G.W. 2002. Using satellite telemetry to define spatial population structure in polar bears in the Norwegian and western Russian Arctic. Journal of Applied Ecology 39, 79-90.

McKinney M.A., Iverson S., Fisk A.T., Sonne C., Rigét F.F., Letcher R.J., Arts M.T., Born E.W., Rosing-Asvid A. \& Dietz R. 2013. Global change effects on the long-term feeding ecology and contaminant exposures of East Greenland polar bears. Global Change Biology 19, 2360-2372. 
McKinney M.A., Letcher R.J., Aars J., Born E.W., Branigan M., Dietz R., Evans T.J., Gabrielsen G.W., Peacock E. \& Sonne C. 2011. Flame retardants and legacy contaminants in polar bears from Alaska, Canada, East Greenland and Svalbard, 2005-2008. Environment International 37, 365-374.

Mckinney M.A., Peacock E. \& Letcher R.J. 2009. Sea iceassociated diet change increases the level of chlorinated and bromiated contaminants in polar bears. Environmental Science e Technology 43, 4334-4339.

Molnár P.K., Derocher A.E., Klanjscek T. \& Lewis M.A. 2011. Predicting climate change impacts on polar bear litter size. Nature Communications 2, 186.

Molnár P.K., Derocher A.E., Lewis M.A. \& Taylor M.K. 2008. Modelling the mating system of polar bears: a mechanistic approach to the allee effect. Proceedings of the Royal Society $B$ 275, 217-226.

Molnár P.K., Derocher A.E., Thiemann G.W. \& Lewis M.A. 2010. Predicting survival, reproduction and abundance of polar bears under climate change. Biological Conservation 143, 1612-1622.

Molnár P.K., Klanjscek T., Derocher A.E., Obbard M.E. \& Lewis M.A. 2009. A body composition model to estimate mammalian energy stores and metabolic rates from body mass and body length, with application to polar bears. Journal of Experimental Biology 212, 2313-2323.

Morales J.M., Haydon D.T., Frair J., Holsiner K.E. \& Fryxell J.M. 2004. Extracting more out of relocation data: building movement models as mixtures of random walks. Ecology 85 , 2436-2445.

Muir D.C.G., Backus S., Derocher A.E., Dietz R., Evans T.J., Gabrielsen G.W., Nagy J., Norstrom R.J., Sonne C., Stirling I., Taylor M.K. \& Letcher R.J. 2006. Brominated flame retardants in polar bears (Ursus maritimus) from Alaska, the Canadian Arctic, East Greenland, and Svalbard. Environmental Science $\theta$ Technology 40, 449-455.

Muir D.C.G., Norstrom R.J. \& Simon M. 1988. Organochlorine contaminants in the Arctic marine food chains: accumulation of specific polychlorinated biphenyls and chlordanerelated compounds. Environmental Science \& Technology 22, 1071-1079.

Nilssen K.T., Pedersen O.P., Folkow L.P. \& Haug T. 2000. Food consumption estimates of Barents Sea harp seals. NAMMCO Scientific Publications 2, 9-27.

Nilsson A.E. \& Huntington H.P. 2009. Arctic pollution 2009. Oslo: Arctic Monitoring and Assessment Programme.

Nordøy E.S., Folkow L.P., Potelov V., Prichtchemikhine V. \& Blix A.S. 1998. Migratory patterns and dive behaviour of Barents Sea harp seals. In: Abstracts: the World Marine Mammal Science Conference. Monaco, 20-24 January. P. 97. La Rochelle: Center for Research on Marine Mammals.

Norheim G., Skaare J.U. \& Wiig Ø. 1992. Some heavy metals, essential elements, and chlorinated hydrocarbons in polar bear (Ursus maritimus) at Svalbard. Environmental Pollution $77,51-57$.

Norstrom R.J., Belikov S.E., Born E.W., Garner G.W., Malone B., Olpinski S., Ramsay M.A., Schliebe S., Stirling I., Stishov M.S., Taylor M.K. \& Wiig Ø. 1998. Chlorinated hydrocarbon contaminants in polar bears from eastern Russia, North America, Greenland, and Svalbard: biomonitoring of Arctic pollution. Archives of Environmental Contamination and Toxicology 35, 354-367.

Obbard M.E., Thiemann G.W., Peacock E. \& DeBruyn T.D. (eds.) 2010. Polar bears. Proceedings of the 15th working meeting of the IUCN Polar Bear Specialist Group, 29 June-3 July 2009. Copenhagen, Denmark. Occasional Paper of the IUCN Species Survival Commission 43. Gland: International Union for the Conservation of Nature.

Oehme M. 1991. Dispersion and transport paths of toxic persistent organochlorines to Arctic-levels and consequences. Science of the Total Environment 106, 43-53.

Oksanen A., Åsbakk K., Prestrud K.W., Aars J., Derocher A.E., Tryland M., Wiig Ø., Dubey J.P., Sonne C., Dietz R., Andersen M. \& Born E.W. 2009. Prevalence of antibodies against Toxoplasma gondii in polar bears (Ursus maritimus) from Svalbard and East Greenland. Journal of Parasitology 95, 89-94.

Olsen G.H., Mauritzen M., Derocher A.E., Sørmo E.G., Skaare J.U., Wiig Ø. \& Jenssen B.M. 2003. Space-use strategy is an important determinant of PCB concentrations in female polar bears in the Barents Sea. Environmental Science e Technology 37, 4919-4924.

Olsson M., Andersson Ö., Bergman Å., Blomkvist G., Frank A. \& Rappe C. 1992. Contaminants and diseases in seals from Swedish waters. Ambio 21, 561-562.

Øritsland N.A. 1970. Temperature regulation of the polar bear (Thalarctos maritimus). Journal of Comparable Biochemistry and Physiology Series A 37, 225-233.

Oskam I.C., Ropstad E., Dahl E., Lie E., Derocher A.E., Wiig Ø., Larsen S., Wiger R. \& Skaare J.U. 2003. Organochlorines affect the major androgenic hormone, testosterone, in male polar bears (Ursus maritimus) at Svalbard. Journal of Toxicology and Environmental Health Part A 66, 2119-2139.

Oskam I.C., Ropstad E., Lie E., Derocher A.E., Wiig Ø., Dahl E., Larsen S. \& Skaare J.U. 2004. Organochlorines affect the steroid hormone cortisol in free-ranging polar bears (Ursus maritimus) at Svalbard, Norway. Journal of Toxicology and Environmental Health Part A 67, 959-977.

Overrein Ø. 2002. Virkninger av motorferdsel på fauna og vegetasjon: kunnskapsstatus med relevans for Svalbard. (Effects of motorized traffic on fauna and vegetation: the status of knowledge relevant for Svalbard.) Report Series 119. Tromsø: Norwegian Polar Institute.

Parks E.K., Derocher A.E. \& Lunn N.J. 2006. Seasonal and annual movement patterns of polar bears on the sea ice of Hudson Bay. Canadian Journal of Zoology 84, 1281-1294.

Parovshchikov V.Y. 1964. A study on the population of polar bear, Ursus (Thalarctos) maritimus Phipps, of Franz Joseph Land. Acta Societatis Zoologicae Bohemoslovenicae 28, 167-177.

Pentreath R.J., Jefferies D.F., Talbot J.W., Lovett M.B. \& Harvey B.R. 1982. Transuranic cycling behaviour in marine environment. IAEA-TECDOC-265. Vienna: International Atomic Energy Agency. 
Pilfold N.W., Derocher A.E., Stirling I., Richardson E. $\delta$ Andriashek D. 2012. Age and sex composition of seals killed by polar bears in the Eastern Beaufort Sea. PLoS One 7(7), e41429, doi: 10.1371/journal.pone.0041429.

Polar Bear Range States 2015. Circumpolar action plan: conservation strategy for polar bears. A product of the representatives of the parties to the 1973 Agreement on the Conservation of Polar Bears. Accessed on the internet at http://naalakkersuisut.gl/en/ Naalakkersuisut/Departments/Fiskeri-Fangst-og-Landbrug/ Isbjorn/The-Circumpolar-Action-Plan-and-ExecutiveSummary on 21 June 2016

Polischuk S.C. 1999. Organochlorine dynamics in free-ranging polar bears and their cubs. PhD thesis, University of Saskatchewan.

Polischuk S.C., Norstrom R.J. \& Ramsay M.A. 2002. Body burdens and tissue concentrations of organochlorines in polar bears (Ursus maritimus) vary during seasonal fasts. Environmental Pollution 118, 29-39.

Prestrud P. \& Stirling I. 1994. The international Polar Bear Agreement and the current status of polar bear conservation. Aquatic Mammals 20, 1-12.

Ramsay M. \& Stirling I. 1990. Fidelity of female polar bears to winter den sites. Journal of Mammalogy 71, 233-236.

Reeves R.R. 1998. Distribution, abundance and biology of ringed seals (Phoca hispida): an overview. NAMMCO Scientific Publications 1, 9-45.

Regehr E.V., Hunter C.M., Caswell H., Amstrup S.C. \& Stirling I. 2010. Survival and breeding of polar bears in the southern Beaufort Sea in relation to sea ice. Journal of Animal Ecology 79, 117-127.

Regehr E.V., Lunn N.J., Amstrup S.C. \& Stirling L. 2007. Effects of earlier sea ice breakup on survival and population size of polar bears in western Hudson Bay. Journal of Wildlife Management 71, 2673-2683.

Richardson E., Stirling I. \& Hik D.S. 2005. Polar bear (Ursus maritimus) maternity denning habitat in western Hudson Bay: a bottom-up approach to resource selection functions. Canadian Journal of Zoology 83, 860-870.

Rigét F., Bossi R., Sonne C., Vorkamp K. \& Dietz R. 2013. Trends of perfluorochemicals in Greenland ringed seals and polar bears: indications of shifts to decreasing trends. Chemosphere 93, 1607-1614.

Rode K.D., Amstrup S.C. \& Regehr E.V. 2010. Reduced body size and cub recruitment in polar bears associated with sea ice decline. Ecological Applications 20, 768-782.

Rondinini C., Rodrigues A.S.L. \& Boitani L. 2011. The key elements of a comprehensive global mammal conservation strategy. Philosophical Transactions of the Royal Society B 355, 2591-2597.

Sahanatien V. \& Derocher A.E. 2012. Monitoring sea ice habitat fragmentation for polar bear conservation. Animal Conservation 15, 397-406.

Sander G., Hanssen-Bauer I., Bjørge A. \& Prestrud P. 2005. Miljøovervåking av Svalbard og Jan Mayen -MOSJ. Report Series 123. Tromsø: Norwegian Polar Institute.

Shapiro I., Colony R. \& Vinje T. 2003. April sea ice extent in the Barents Sea, 1850-2001. Polar Research 22, 5-10.
Skaare J.U., Bernhoft A., Derocher A., Gabrielsen G.W., Goksøyr A., Henriksen E., Larsen H.J., Lie E. \& Wiig Ø. 2000. Organochlorines in top predators at Svalbardoccurrence, levels and effects. Toxicological Letters 112/113, 103-109.

Smith T.G. 1980. Polar bear predation of ringed and bearded seals in the land-fast sea ice habitat. Canadian Journal of Zoology 58, 2201-2209.

Smith T.G. \& Lydersen C. 1991. Availability of suitable land-fast ice and predation as factors limiting ringed seal populations, Phoca hispida, in Svalbard. Polar Research 10, 585-594

Smith T.G. \& Stirling I. 1975. The breeding habitat of the ringed seal (Phoca hispida). The birth lair and associated structures. Canadian Journal of Zoology 53, 1297-1305.

Sonne C. 2010. Health effects from long-range transported contaminants in Arctic top predators: an integrated review based on studies of polar bears and relevant model species. Environmental International 36, 461-491.

Stirling I. 1974. Midsummer observations on behavior of wild polar bears (Ursus maritimus). Canadian Journal of Zoology 52, 1191-1198.

Stirling I. \& Andriashek D. 1992. Terrestrial maternity denning of polar bears in the eastern Beaufort Sea area. Arctic 45, 363-366.

Stirling I., Andriashek D. \& Calvert W. 1993. Habitat preferences of polar bears in the western Canadian Arctic in late winter and spring. Polar Record 29, 13-24.

Stirling I. \& Archibald W.R. 1977. Aspects of predation of seals by polar bears. Journal of the Fisheries Research Board of Canada 34, 1126-1129.

Stirling I. \& Derocher A.E. 1993. Possible impacts of climatic warming on polar bears. Arctic 46, 240-245.

Stirling I. \& Derocher A.E. 2012. Effects of climate warming on polar bears: a review of the evidence. Global Change Biology 18, 2694-2706.

Stirling I., Lunn N.J. \& Iacozza J. 1999. Long-term trends in the population ecology of polar bears in western Hudson Bay in relation to climatic change. Arctic 52, 294-306.

Stirling I. \& McEwan E.H. 1975. Caloric value of whole ringed seals (Phoca hispida) in relation to polar bear (Ursus maritimus) ecology and hunting behavior. Canadian Journal of Zoology 53, 1021-1027.

Strand P., Howard B.J., Aarkrog A., Balonov M., Tsaturov Y., Bewers J.M., Salo A., Sickel M., Bergman R. \& Rissanen K. 2002. Radioactive contamination in the Arctic-sources, dose assessment and potential risks. Journal of Environmental Radioactivity 60, 5-21.

Taylor M.K., Demaster D.P., Bunnell F.L. \& Schweinsburg R.E. 1987. Modelling the sustainable harvest of female polar bears. Journal of Wildlife Management 51, 811-820.

Taylor M.K., Laake J., McLoughlin P.D., Born E.W., Cluff H.D., Ferguson S.H., Rosing-Asvid A., Schweinsburg R. \& Messier F. 2005. Demography and viability of a hunted population of polar bears. Arctic 58, 203-214. 
Taylor M.K. \& Lee L.J. 1995. Distribution and abundance of Canadian polar bear populations: a management perspective. Arctic 48, 147-154.

Thiemann G.W., Iverson S.J. \& Stirling I. 2008. Polar bear diets and Arctic marine food webs: insights from fatty acid analysis. Ecological Monographs 78, 591-613.

Tryland M., Derocher A.E., Wiig Ø. \& Godfroid J. 2001. Brucella sp antibodies in polar bears from Svalbard and the Barents Sea. Journal of Wildife Diseases 37, 523-531.

Tryland M., Neuvonen E., Huovilainen A., Tapiovaara H., Osterhaus A., Wiig O. \& Derocher A.E. 2005. Serologic survey for selected virus infections in polar bears at Svalbard. Journal of Wildlife Diseases 41, 310-316.

Verreault J., Muir D.C.G., Norstrom R.J., Stirling I., Fisk A.T., Gabrielsen G.W., Derocher A.E., Evans T., Dietz R., Sonne C., Sandala G.M., Taylor M.K., Nagy J. \& Letcher R.J. 2005. Chlorinated hydrocarbon contaminants and metabolites in polar bears (Ursus maritimus) from Svalbard, East Greenland, Alaska and the Canadian Arctic during 1999-2002. Science of the Total Environment 351, 369-390.

Villanger G.D., Jenssen B.M., Fjeldberg R.R., Letcher R.J., Muir D.C.G., Kirkegaard M., Sonne C. \& Dietz R. 2011. Exposure to mixtures of organohalogen contaminants and associative interactions with thyroid hormones in East Greenland polar bears (Ursus maritimus). Environment International 37, 694-708.

Vinebrooke R.D., Cottingham K.L., Norberg J., Scheffer M., Dodson S.I., Maberly S.C. \& Sommer U. 2004. Impacts of multiple stressors on biodiversity and ecosystem functioning: the role of species co-tolerance. Oikos 104, 451-457.

Vongraven D. 2009. Guest editorial: the ballyhoo over polar bears. Polar Research 28, 323-326.

Vongraven D., Aars J., Amstrup S., Atkinson S.N., Belikov S.E., Born E.W., DeBruyn T.D., Derocher A.E., Durner G., Gill M., Lunn N., Obbard M.E., Omelak J., Ovsyanikov N., Peacock E., Richardson E., Sahanatien V., Stirling I. \& Wiig Ø. 2012. A circumpolar monitoring framework for polar bears. Ursus Monograph Series 5. Ursus 23, 1-66.

Vongraven D. \& Peacock E. 2011. Development of a pan-Arctic monitoring plan for polar bears: background paper. CAFF
Monitoring Series Report 1. Akureyri: Conservation of Arctic Flora and Fauna .

Watts P.D. \& Hansen S.E. 1987. Cyclic starvation as a reproductive strategy in the polar bear. Symposia of the Zoological Society of London 57, 305-318.

Wiig Ø. 1995. Distribution of polar bears (Ursus maritimus) in the Svalbard area. Journal of Zoology 237, 515-529.

Wiig Ø. 1998. Survival and reproductive rates for polar bears at Svalbard. Ursus 10, 25-32.

Wiig Ø. 2005. Are polar bears threatened? Science 309, $1814-1815$.

Wiig Ø., Aars J. \& Born E.W. 2008. Effects of climate change on polar bears. Science Progress 91, 151-173.

Wiig Ø., Amstrup S., Atwood T., Laidre K., Lunn N., Obbard M., Regehr E. \& Thiemann G. 2015. Ursus maritimus. The IUCN Red List of threatened species 2015, e.T22823A14871490, http://dx.doi.org/10.2305/IUCN.UK.2015-4.RLTS.T22823A 14871490.en. Accessed on the internet at http://www. iucnredlist.org/details/22823/0 on 27 May 2016

Wiig Ø. \& Derocher A. 1999. Application of aerial survey methods to polar bears in the Barents Sea. In G.W. Garner et al. (eds.): Marine mammal survey and assessment methods. Pp. 27-36. Rotterdam: Balkema.

Wiig Ø., Derocher A.E. \& Belikov S.E. 1999. Ringed seal (Phoca hispida) breeding in the drifting pack ice of the Barents Sea. Marine Mammal Science 15, 595-598.

Wilson K.A., Evans M.C., Di Marco M., Green D.C., Boitani L., Possingham H.P., Chiozza F. \& Rondinini C. 2011. Prioritizing conservation investments for mammal species globally. Philosophical Transactions of the Royal Society B 366, 2670-2680.

Wolkers H., Krafft B.A., van Bavel B., Helgason L.B., Lydersen C. \& Kovacs K.M. 2008. Biomarker responses and decreasing contaminant levels in ringed seals (Pusa hispida) from Svalbard, Norway. Journal of Toxicology and Environmental Health 71, 1009-1018.

Yasuda T. \& Arai N. 2005. Fine-scale tracking of marine turtles using GPS-Argos PTTs. Zoological Science 22, 547-553.

Zeyl E., Ehrich D., Aars J., Bachmann L. \& Wiig Ø. 2010. Denning-area fidelity and mitochondrial DNA diversity of female polar bears (Ursus maritimus) in the Barents Sea. Canadian Journal of Zoology 88, 1139-1148. 